\title{
Comparative micromorphology and anatomy of seeds and endocarps of selected Primulaceae and their systematic implications
}

\author{
Maria Morozowska $^{1}$ D $\cdot$ Maria de F. Freitas $^{2} \mathbb{D} \cdot$ Bruna N. de Luna $^{2}$ (D) Karen L. G. De Toni ${ }^{2}$ (D)
}

Received: 22 August 2019 / Accepted: 27 June 2020 / Published online: 3 August 2020

(c) The Author(s) 2020

\begin{abstract}
Seed and endocarp micromorphology and anatomy of 16 taxa from the genera Ardisia, Geissanthus, Stylogyne, Myrsine (Myrsinoideae), and Jacquinia (Theophrastoideae) were examined using stereo- and scanning electron microscopy and discussed in the light of the current phylogenetic framework. In all species, the ornamentation of the seed surface was reticulate, tuberculate, or tuberculate-colliculate with several differences concerning the cell outline and anticlinal cell wall boundaries. For seeds of almost all Myrsinoideae species, one-layered seed coat devoid of rhomboid or prismatic crystals was characteristic, while seeds of J. armillaris had a two-layered seed coat with prismatic crystals. The one-layered seed coat in Myrsinoideae may be considered a synapomorphy of this subfamily. The endosperm tissue in seeds of Myrsinoideae was differentiated into two types. Seeds of Ardisia and Geissanthus species were characterized by 'pitted' endosperm, while in seeds of Myrsine species both the 'pitted' endosperm and endosperm with evenly thickened cell walls were present. In seeds of Theophrastoideae, the endosperm was 'pitted.' Our results confirmed that the concave hilum area is characteristic of subglobose seeds of Myrsinoideae. The ruminate endosperm was present in all the examined Myrsine species, but it was absent in Ardisia crenata, Geissanthus ambiguus, and Stylogyne pauciflora seeds. Thus, the ruminate endosperm is not the feature clearly distinguishing the seeds of Myrsinoideae and Theophrastoideae. Endocarps of Myrsinoideae vary in terms of their morphology and anatomy. The variation within the primary and secondary sculpture of their inner surface and the presence of stomata in endocarps of particular species may have systematic implications.
\end{abstract}

Keywords Ardisia $\cdot$ Geissanthus $\cdot$ Jacquinia Myrsine $\cdot$ Ruminate endosperm $\cdot$ Seed coat $\cdot$ Stylogyne

\section{Introduction}

Handling Editor: Mike Thiv.

Electronic supplementary material The online version of this article (https://doi.org/10.1007/s00606-020-01699-z) contains supplementary material, which is available to authorized users.

Maria Morozowska

maria.morozowska@up.poznan.pl

Maria de F. Freitas

ffreitas@jbrj.gov.br

Bruna N. de Luna

brunanunes.luna@gmail.com

Karen L. G. De Toni

karen.detoni@gmail.com

1 Department of Botany, Poznań University of Life Sciences, Wojska Polskiego 71 C, 60-625 Poznań, Poland

2 Instituto de Pesquisas Jardim Botânico do Rio de Janeiro, Diretoria de Pesquisas, Rua Pacheco Leão 915, Rio de Janeiro CEP 22460-030, Brazil
Primulaceae (Order Ericales) is a monophyletic family with four subfamilies (Maesoideae, Myrsinoideae, Primuloideae, and Theophrastoideae) that comprises 2590 species widely distributed worldwide (APG IV 2016). This current circumscription was due to exhaustive morphological (Anderberg and Ståhl 1995) and molecular surveys (Anderberg et al. 1998, 2000; Källersjö et al. 2000; Schönenberger et al. 2005) that helped to clarify the boundaries in the previously called 'primuloid group,' that were formed by the currently excluded families Maesaceae, Myrsinaceae, Primulaceae, and Theophrastaceae.

Despite the unquestionable monophyly of the family, many generic and species boundaries still lack delimitation. In this sense, morphology, wood, and leaf anatomy and several different types of secretory tissues are used as highly informative taxonomic characteristics to distinguish particular genera, subfamilies, or clades within Primulaceae. 
Such features are also helpful in phylogenetic analyses based on mixed molecular, morphological, and anatomical data (Källersjö et al. 2000; Källersjö and Ståhl 2003; Lens et al. 2005; Luna et al. 2013, 2014, 2017, 2018, 2019). Although fruits and seeds of Primulaceae species, including both herbaceous (Primuloidae and Myrsinoidae) and woody plants (Myrsinoidae and Theophrastoidae), have been examined according to their development, morphology, and anatomy, the obtained results were rather ambiguous regarding systematics and phylogeny of the studied plants (Otegui et al. 1998b; Otegui and Cocucci 1999; Anderberg et al. 2007; Oh et al. 2008; Morozowska et al. 2011).

Otegui et al. (1998a, b, 1999a, b), who performed studies on secretory structures, seed structure, and endosperm development of Myrsine laetevirens, confirmed the rumination of the seeds and the type of the 'pitted' endosperm cell walls to be typical for the examined species. The ruminations, assumed to be typical for the large subglobose seeds of Myrsinoideae, were at first thought to be caused by the activity of the seed coat or the endosperm itself during later stages of seed development (Corner 1976; Anderberg and Ståhl 1995). However, Otegui et al. (1998a) showed that in $M$. laetevirens seeds the indentations responsible for their lobed outline are formed from crystals secreted by the placenta, which surrounds the developing seed. The same authors found that in the ovules of $M$. laetevirens, the groups of secretory cells in the epidermis of the placenta secrete pure rapanone, the main constituent of seed crystals. They also suggested that a similar situation could be expected in other genera of Myrsinoideae.

The seeds of Primulaceae are differentiated based on their morphology and anatomy. According to Anderberg and Ståhl (1995) and Anderberg and Kelso (1996), two types of seeds were described within Primulaceae (previously called 'primuloid clade'). Most genera of the former families Theophrastaceae and Myrsinaceae were supposed to have rather large, subglobose seeds with a thin testa devoid of crystals and a 'pitted' endosperm (very thick endosperm cell walls with irregular thickenings). The main differences between these two families concerned the concave hilum area and a more or less ruminate endosperm observed in Myrsinaceae seeds. In turn, almost all of the former Primulaceae and the genus Maesa were characterized by having small angular seeds with a thick, usually distinctly two-layered testa with rhomboid crystals and smooth, evenly thickened endosperm cell walls (Anderberg and Ståhl 1995).

Although it is well known that fruit and seed morphology and anatomy are of considerable importance in plant taxonomy, data gathered on Theophrastoideae and Myrsinoideae are rather limited and most of the available information concerns the herbaceous taxa (Oh et al. 2008; Morozowska et al. 2011). Oh et al. (2008), who examined seed morphology in the genus Lysimachia and related taxa, found that the seed coat structure provides potentially synapomorphic character states for various subclades of Lysimachia. Morozowska et al. (2011) examined several herbaceous species of Primuloideae, Myrsinoideae, and Theophrastoideae and provided new and important data concerning seed shape and size, seed coat sculpture, thickness and structure, the presence of oxalate crystals in testa, and the endosperm structure. According to the cited authors, most of the described characters were poorly correlated with major clades; however, some of them were recognized as potentially informative characters, which may support molecular evidence in resolving unclear relationships between species, genera, or subfamilies of Primulaceae.

The present study is a continuation in a series of papers that started with Morozowska et al. (2011) discussing seed and endocarp morpho-anatomy in some Primulaceae herbaceous species. In the present work, we examined fruit and seed morphology and anatomy in several woody Myrsinoideae and Theophrastoideae species to provide additional information on their reproductive structures that are still little known in Primulaceae. The taxonomic importance and systematic implications of the results are discussed in a phylogenetic framework. Furthermore, we provided a compilation of the earlier and presently obtained results to discuss our findings in a broader context regarding the entire Primulaceae family.

\section{Materials and methods}

The material studied comprises woody representatives of two subfamilies: the pantropical Myrsinoideae and the neotropical Theophrastoideae from Primulaceae. We analyzed plants found in a variety of habitats. Thirteen of the examined species represent Brazilian flora (Carrijo et al. 2012; Freitas and Kinoshita 2015; Freitas et al. 2017), while Myrsine wightiana is native to India and is also distributed in Sri Lanka (Sasidharan n.d.), the Myrsine africana native range comprises ES Africa, the Arabian Peninsula, China, and the Azores, while the native range of Ardisia sieboldii is SE China and Temperate E Asia (WFO 2018).

Morphological and anatomical fruit and seed characters of nine Myrsine, four Ardisia, one Stylogyne, and one Geissanthus species representing Myrsinoideae, as well as $\mathrm{Jac}$ quinia armillaris of Theophrastoideae, were examined by stereomicroscopy and scanning electron microscopy (SEM) using plant material obtained from various herbarium collections (Table 1). Seed coat thickness was measured on the longitudinal and cross-sections of ten seeds from each species based on scanning electron microscope images. Before cutting, fruits and seeds were rehydrated for $24 \mathrm{~h}$ in water, brushed clean, rinsed in distilled water (two times for $10 \mathrm{~min}$ ), and sectioned. After sectioning, the hand cuttings 
Table 1 List of species analyzed in the study

\begin{tabular}{|c|c|c|c|}
\hline Subfamily & Species & Voucher/source reference & Figures \\
\hline Myrsinoideae & Ardisia crenata Sims & Hotrus Botanicus Tallinnensis, 313, Estonia & $1 \mathrm{a}-\mathrm{c} ; 3 \mathrm{f}, \mathrm{g} ; 5 \mathrm{a}, \mathrm{b}$ \\
\hline Myrsinoideae & Ardisia humilis Vahl & $\begin{array}{l}\text { Botanischer Garten der Universität Tübingen, } \\
\text { 1007, xx-0-TUEB-1292, Germany }\end{array}$ & $1 \mathrm{f}, \mathrm{g} ; 3 \mathrm{a}, \mathrm{b} ; 5 \mathrm{c}-\mathrm{h}$ \\
\hline Myrsinoideae & Ardisia sieboldii Miq & $\begin{array}{l}\text { Władysław Szafer Institute of Botany, KRAM } \\
\text { 1713, Krakow, Poland }\end{array}$ & $1 \mathrm{~d}, \mathrm{e} ; 5 \mathrm{i}-1$ \\
\hline Myrsinoideae & Ardisia solanacea (Poir.) Roxb. & Palm House Collection, Poznań, Poland & $3 c-e ; 4 a-e$ \\
\hline Myrsinoideae & Myrsine africana $\mathrm{L}$. & Hotrus Botanicus Tallinnensis, 357, Estonia & $2 \mathrm{~m}, \mathrm{n} ; 6 \mathrm{a}-\mathrm{e}$ \\
\hline Myrsinoideae & $\begin{array}{l}\text { Myrsine coriacea (Sw.) R.Br. ex Roem. \& } \\
\text { Schult. }\end{array}$ & $\begin{array}{l}\text { Jardim Botanico do Rio de Janerio RB } \\
\text { 476242, Brazil }\end{array}$ & $2 \mathrm{~g}, \mathrm{~h} ; 6 \mathrm{f}-\mathrm{i}$ \\
\hline Myrsinoideae & Myrsine gardneriana A.DC. & $\begin{array}{l}\text { Jardim Botanico do Rio de Janerio RB } \\
\text { 605197, Brazil }\end{array}$ & $2 \mathrm{r}-\mathrm{u} ; 6 \mathrm{j}-\mathrm{m}$ \\
\hline Myrsinoideae & Myrsine guianensis (Aubl.) O.Kuntze & $\begin{array}{l}\text { Jardim Botanico do Rio de Janerio RB } \\
\text { 415746, Brazil }\end{array}$ & 2k, 1; Online Resource 2 \\
\hline Myrsinoideae & Myrsine lineata $(\mathrm{Mez})$ Imkhan. & $\begin{array}{l}\text { Jardim Botanico do Rio de Janerio RB } \\
\text { 605196, Brazil }\end{array}$ & $2 \mathrm{e}, \mathrm{f} ; 6 \mathrm{n}, \mathrm{o}$ \\
\hline Myrsinoideae & Myrsine parvula (Mez) Otegui & $\begin{array}{l}\text { Jardim Botanico do Rio de Janerio RB } \\
\text { 605183, Brazil }\end{array}$ & 2a, b; 3i; Online Resource 2 \\
\hline Myrsinoideae & Myrsine umbellata Mart. & $\begin{array}{l}\text { Jardim Botanico do Rio de Janerio RB } \\
\text { 605182, Brazil }\end{array}$ & $2 \mathrm{i}, \mathrm{j}$ \\
\hline Myrsinoideae & Myrsine venosa A.DC. & $\begin{array}{l}\text { Jardim Botanico do Rio de Janerio RB } \\
\text { 558145, Brazil }\end{array}$ & 2c, d; 3h; Online Resource 2 \\
\hline Myrsinoideae & Myrsine wightiana Wall. ex A.DC. & $\begin{array}{l}\text { W. Szafer Institute of Botany KRAM 1712, } \\
\text { Krakow, Poland }\end{array}$ & 2o, p; 3j; Online Resource 2 \\
\hline Myrsinoideae & Geissanthus ambiguus (Mart.) G.Agostini & $\begin{array}{l}\text { Jardim Botanico do Rio de Janerio RB 68058, } \\
\text { Brazil }\end{array}$ & $1 \mathrm{~h}-\mathrm{j} ; 3 \mathrm{k}-\mathrm{m} ; 4 \mathrm{f}-\mathrm{i}$ \\
\hline Myrsinoideae & Stylogyne pauciflora Mez & $\begin{array}{l}\text { Jardim Botanico do Rio de Janerio RB } \\
531571\end{array}$ & $1 \mathrm{k}-1 ; 3 \mathrm{n}, \mathrm{o}$ \\
\hline Theophrastoideae & Jacquinia armillaris Jacq. & $\begin{array}{l}\text { Jardim Botanico do Rio de Janerio RB } \\
\text { 583208, Brazil }\end{array}$ & $3 p ; 7 a-h$ \\
\hline
\end{tabular}

were dried using an acetone series of 30\%, 50\%, 70\%, $90 \%$, and $100 \%$, three times for $6 \mathrm{~min}$ in each. For SEM examinations, seeds and fruits as well as their cuttings were gold-sputtered and examined under a Zeiss EVO 40 electron microscope at $8-15 \mathrm{kV}$ depending on the species. The terminology used to describe fruit and seed ultrastructure follows Barthlott (1981) and Barthlott et al. (1998).

\section{Phylogeny and character optimization}

Phylogenetic relationships were inferred from $r b c \mathrm{~L}$ sequences from Genbank accessions (see Supplementary Electronic Material) of 12 Primulaceae genera, representing the four subfamilies. Diospyros virginiana (Ebenaceae) and Manilkara zapota (Sapotaceae) were selected as outgroups, as both families are sister groups of Primulaceae (Schönenberger et al. 2005).

A heuristic search was performed with 5000 repetitions and 100 trees per replication using TBR swapping, based on the character optimization method ACCTRAN (accelerated transformation optimization; Farris 1970, Swofford and Maddison 1987), with unordered characters of equal weight and the retention of multiple most parsimonious trees (MAXTREE) using maximum parsimony in PAUP* version 4.0b10 for Windows (Swofford 2002). Bootstrap analysis was performed with a random addition sequence of taxa, using TBR for 1000 replicates (Felsenstein 1985) to provide node support values.

To trace character evolution, 11 were plotted using parsimony optimization on one of the most parsimonious trees obtained from the phylogenetic analysis using the Mesquite software (Maddison and Maddison 2018) with parsimony optimization. Additional anatomical data on Androsace, Primula, Soldanella (Primuloideae), Samolus (Theophrastoideae), Cyclamen, and Lysimachia (Myrsinoideae) were taken from the literature (Morozowska et al. 2011). The selected characters and their states are presented in Table 2, while the character states of the studied Primulaceae genera are shown in Table 3. 
Table 2 Seed and endocarp selected characters and character states

\begin{tabular}{|c|c|}
\hline Character & Character states \\
\hline Secondary sculpture of the endocarp & 0—smooth; 1-micro-reticulate; 2-foveolate; 3-verrucose; 4-striate; 5-absent \\
\hline Hilum shape & 0—depressed; 1—narrow; 2-narrowly elliptic; 3-elliptic; 4-circular \\
\hline Seed coat cellular pattern & 0-reticulate; 1 -tuberculate; 2 -weakly reticulate; 3 -poroid-alveolate; 4 -vesiculose \\
\hline Endosperm cell walls & $\begin{array}{l}0 \text { - evenly thickened, smooth; } 1 \text { - unevenly thickened, pitted (= with hollows); } 2 \text {-thin, } \\
\text { paper-like; } 3 \text {-with helical thickenings; } 4 \text {-strongly undulate }\end{array}$ \\
\hline Number of sclerenchyma cell layers in the endocarp & $0-1 ; 1-2 ; 2-3 ; 3-4 ; 4-5 ; 5-$ absent \\
\hline Differentiation of the endosperm into layers & 0 -absent; 1 -present \\
\hline Seed coat structure & $0-1$ layered; $1-2$ layered \\
\hline Stomata in the inner surface of the endocarp & 0 -absent; 1 -present \\
\hline Seed shape & 0—subglobose; 1 —sectoroid; 2—polyhedral; 3—ovoid \\
\hline Calcium oxalate crystals in the seed coat & 0 -absent; 1 -present \\
\hline Cellular pattern of the endocarp inner surface & 0 -reticulate; 1 -reticulate-striated; 0 -absent \\
\hline
\end{tabular}

\section{Results}

All the examined woody Myrsinoideae representing the genera Ardisia, Myrsine, Geissanthus, and Stylogyne were characterized by their fleshy drupe fruits with one subglobose seed inside, while in Jacquinia armillaris from Theophrastoideae fruits are berries with 3-4 subglobose seeds.

Stony endocarps of drupes in all the examined Myrsinoideae species are longitudinally ribbed with vascular elements present in the strands of tissues running in the meridian orientation on the endocarp surface (Fig. 1a). Endocarps of Myrsinoideae were composed of 1-4(5) layers of very thick-walled isodiametric or slightly elongated sclerenchyma cells with numerous pits (Table 4). In the endocarps of most examined species sclerenchyma cells were radially orientated, whereas in the endocarps of Ardisia sieboldii, Myrsine venosa, and M. guianensis they were also tangentially orientated (Figs. 1d, 2c, k). Sclerenchyma cells were characterized by the lamellar structure of their secondary cell walls (Fig. 2a), whereas in A. humilis endocarps many rhomboid or prismatic crystals were present (Fig. 1f). Endocarps of all the examined Ardisia species, Geissanthus ambiguus, and Stylogyne pauciflora were composed of only one layer of sclerenchyma, while endocarps of Myrsine most often consisted of 2-4(5) sclerenchyma layers (Figs. 1b, d, f, h, k, 2a, c, e, g, i, k, m, o, t).

The cellular pattern on the endocarp surface was reticulate or reticulate-striated. The cells on the inner surface of endocarps in all the examined species were often polygonate, either equal- or elongate-sided, with straight or acute endings, or they were more or less rounded in their outline. Anticlinal cell wall boundaries were straight, raised, or depressed, while the periclinal walls were flat, concave, or convex. The secondary sculpture of the periclinal walls was micro-reticulate, verrucose, foveate, or foveolate (Table 4; Fig. 2b, d, f, h, j, l, n, p, u). Additionally, in the endocarps of Ardisia humilis, Geissanthus ambiguus, and Stylogyne pauciflora, numerous stomata were observed on the inner surface of the endocarp (Fig. 1g, j, l).

The hilum of seeds in all accessions of Myrsinoideae was more or less depressed (Fig. 3b, e, g, m, o). Additionally, seeds of all Myrsine, A. humilis, and A. solanacea were ruminated in outline with numerable indentations of the seed coat into the endosperm (Figs. 2r, s, 3b, d, e, h, i, j, 4a, 5c, and $6 \mathrm{~g}, \mathrm{~h}, \mathrm{k}$, Online Resource 2). Under the stereomicroscope, these indentations were orange (Fig. 3b, d, e, h, i, $\mathrm{j}$ ), while in SEM they were filled with numerous crystals (Fig. 5c, d, 6h, i, k, Online Resource 2). In seeds of A. sieboldii, the described indentations were rather small (Fig. 5j), while seeds of A. crenata, G. ambiguus, and Stylogyne pauciflora lacked such indentations and they were smooth in the outline (Table 5; Fig. 3g, m, o).

Seeds of all Myrsinoideae were covered by a strongly wrinkled, compressed, membranous tissue of remnants of the placenta (Figs. 3d, g, 1, m, o, 4d, i, 5b, c, h, 6e, Online Resource 2). On the inner surface of placenta remnants groups of secretory cells were observed in seeds of $A$. solanacea (Fig. 4e).

Microsculpturing of Myrsinoideae seeds was either reticulate (Fig. 5e, 6a, f, n), tuberculate (4f, 5i), or tuberculatecolliculate $(6 \mathrm{j})$. The testa surface was often wrinkled, and thus the outline of the epidermal cells was not always clearly visible; however, the surface testa cells in seeds of $A$. creanata, A. solanacea, A. humilis, M. africana, M. coriacea, and $M$. lineata were polygonal in outline with straight, raised anticlinal cell wall boundaries and concave outer periclinal walls (Figs. 4a, 5e, 6a, f,n). In G. ambiguus and A. siebol$d i i$, the outer periclinal walls were convex (Fig. 4f, 5i). The seed coat in all Ardisia, Myrsine, and G. ambiguus was onelayered, undifferentiated, very thin (approx. 2.5-6.95 $\mu \mathrm{m}$ and 6.45-9.09 $\mu \mathrm{m}$, respectively), and devoid of crystals (Table 5, Fig. 6b, d, 1). 


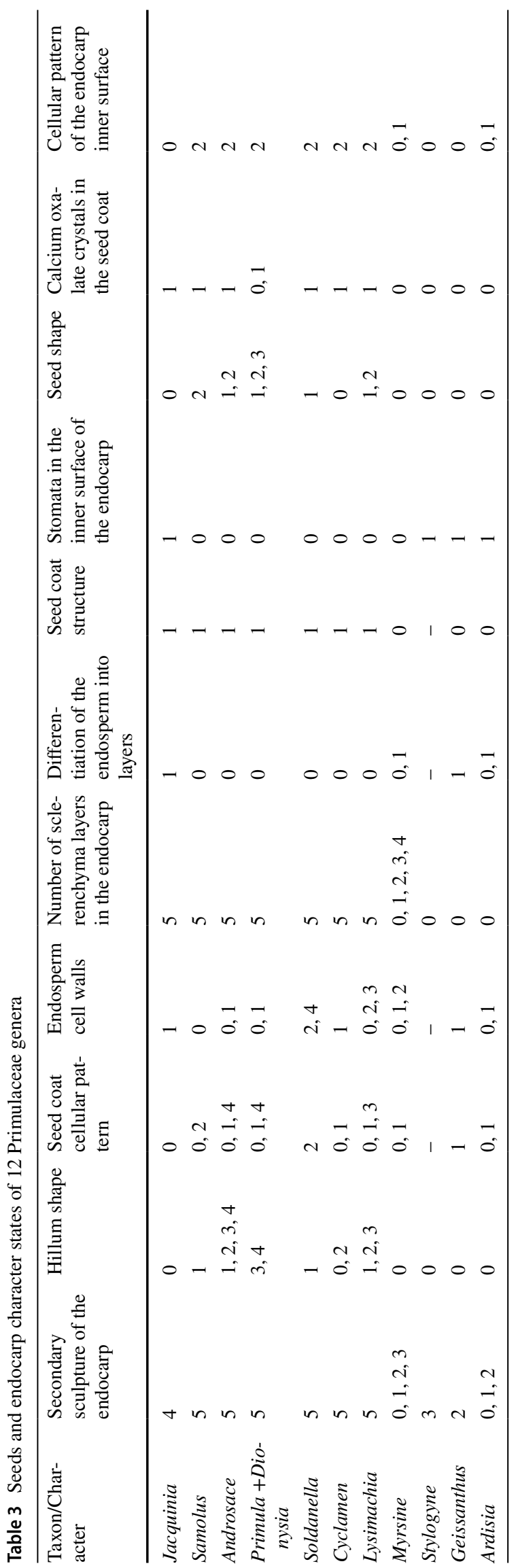

The endosperm of Ardisia, M. africana, M. parvula, and in G. ambiguus was composed of cells with very thick and 'pitted' cell walls (Table 5, Fig. 4b, c, h, 5 g, k, 1, 6b, c, Online Resource 2). In the endosperm of A. crenata also smooth cell walls were observed. Additionally, the endosperm of these species, except $A$. creanata and $A$. siebodii was distinctly differentiated into the outer and the inner parts. Both parts differed according to the cell size and shape, and the cell wall thickness. The outer part of the endosperm consisted of two-three layers of square or rectangular cells with smooth and thin walls, while in the inner part of the endosperm, the cells were elongated, thickwalled, and 'pitted'(Figs. 4b, c, 5f, g, 6b, c, Online Resource 2). In A. solanacea, M. parvula, and Geissanthus ambiguus, the 'pitted' type of endosperm was not as distinct, but still noticeable (Fig. 4c, h, Online Resource 2). In M. lineata and $M$. guianensis, the endosperm cell walls were papery thin, sometimes slightly undulate (Fig. 6o); additionally, in M. guianensis, circular or helical thickenings were present on the inner surfaces of the cell walls (Table 5). In the five other examined Myrsine, the endosperm consisted of cells with smooth and evenly thickened walls, and no differentiation in the endosperm was observed (Table 5, Fig. 61, m, Online Resource 2).

Jacquinia armillaris (Theophrastoideae) berries contained few subglobose seeds with a slightly depressed hilum, and they were entirely surrounded by the placental pulp (Fig. 3p). The exocarp was thin and brittle. The mesocarp and endocarp consisted of several layers of thin-walled, parenchymatic cells. The inner surface of the endocarp was micro-reticulate. The epidermal cells were rounded in outline with straight, raised anticlinal cell wall boundaries and flat outer periclinal walls. The cuticle of these periclinal walls was irregularly striated. Additionally, stomata were present in cells of the inner epidermis of the endocarp (Fig. 7e, h). Testa surface was micro-reticulate and the seed coat was double-layered, approx. $11.20 \mu \mathrm{m}$ in thickness. The outer periclinal walls of the exotesta were flattened or slightly concave, while the anticlinal cell wall boundaries were straight and raised. The mesotesta consisted of several layers of crushed cells with rhomboid or prismatic crystals (Table 5). The tegmen was composed of a solid tissue approx. $1.8 \mu \mathrm{m}$ in thickness (Fig. 7c, d). The 'pitted' endosperm of Jacquinia armillaris seeds was copious and hard, composed of bony cells. Two-three layers of the outer endosperm consisted of cells with smooth and thin walls (Fig. 7a, b).

\section{Phylogenetic analysis}

From 1332 base pair characters in the $r b c L$ sequences, 1078 were constant, 150 were parsimony-uninformative, and 104 were parsimony-informative characters. The parsimony 

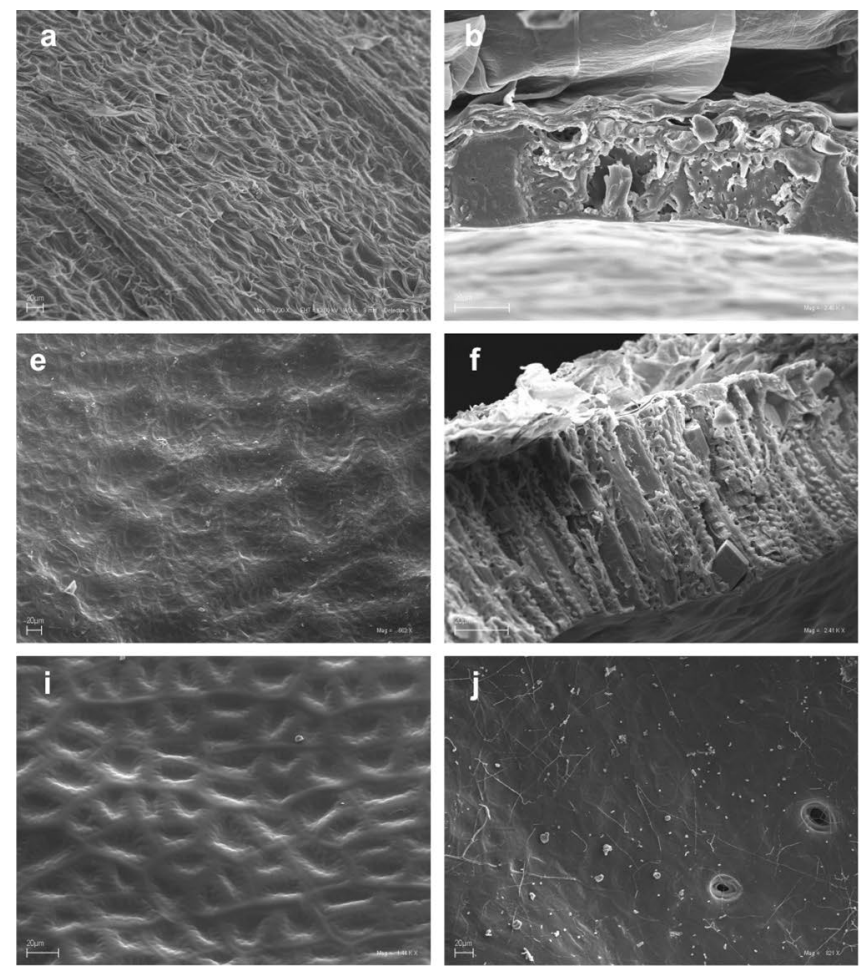

Fig. 1 SEM micrographs of endocarp morphology and anatomy (cross-sections) of Ardisia, Geissanthus, and Stylogyne. a-c Ardisia crenata, a outer surface, $\mathbf{b}$ one layer of almost equally dimensional sclerenchyma cells with numerous pits, $\mathbf{c}$ inner surface with reticulate cellular pattern, raised anticlinal cell wall boundaries, flat periclinal walls; $\mathbf{d}$, e $A$. sieboldii, $\mathbf{d}$ one layer of elongated sclerenchyma cells and one-three layers of tangentially orientated cells (arrows), e inner surface with reticulate cellular pattern, raised anticlinal cell wall boundaries, concave periclinal walls, micro-reticulate/foveolate secondary sculpture; $\mathbf{f}, \mathbf{g}$ A. humilis, $\mathbf{f}$ one layer of strongly elongated

analysis resulted in a single tree with 408 steps. The consistency index was 0.74 , the retention index was 0.56 , and the homoplasy index was 0.26 . Sequence variation in $r b c L$ supports the monophyly of Primulaceae (100\% bootstrap value) and resolves the four subfamilies (Fig. 8a).

\section{Character optimization}

Most of the seed, endosperm, and endocarp characters show some homoplasy (Figs. 9, 10). A depressed hilum was found in Myrsinoideae species and Jacquinia ' (Theophrastoideae) (Fig. 8b). The tuberculate seed coat is shared by both Primuloideae and Myrsinoideae (Fig. 8c). A poroid alveolate seed coat and endosperm cell walls with a helical thickening appear to be apomorphies of Lysimachia (Fig. 8c, d). The differentiation of the endosperm in layers is seen in Ardisia, Myrsine, and Geissanthus from Myrsinoideae, as well as Jacquinia from Theophrastoideae (Fig. 9a).
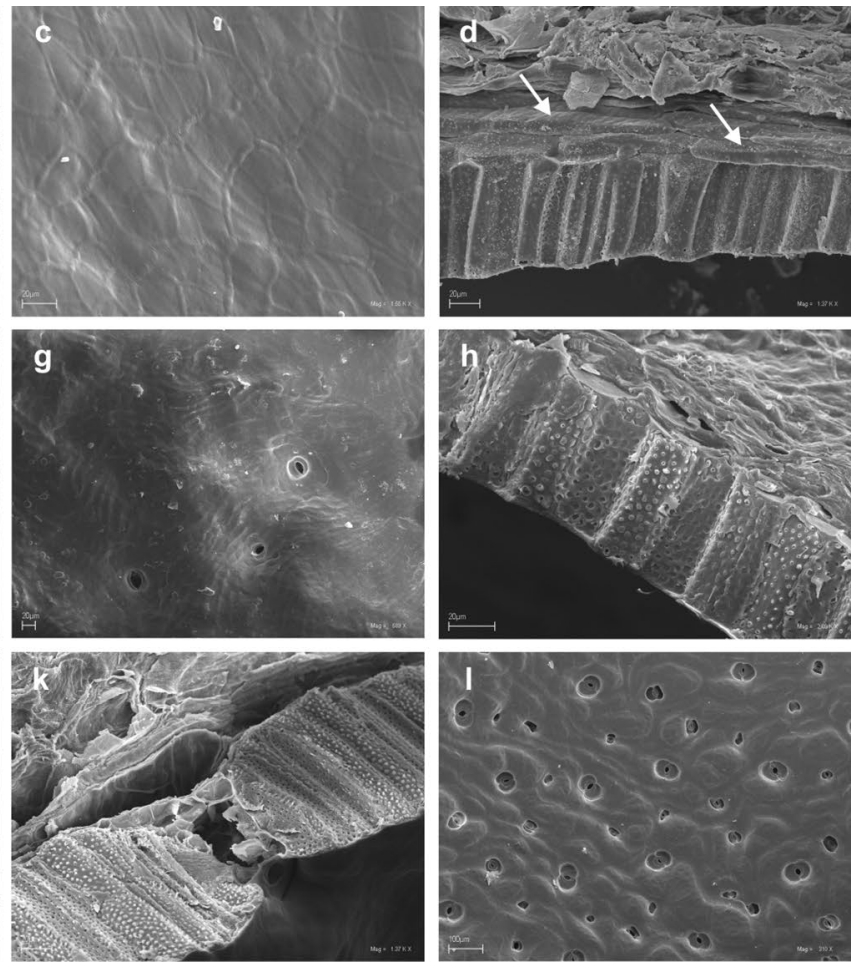

sclerenchyma cells with numerous prismatic crystals, $\mathbf{g}$ inner surface with reticulate-striate cellular pattern, raised anticlinal cell wall boundaries, convex periclinal walls, and stomata; $\mathbf{h}-\mathbf{j}$ Geissanthus ambiguus, $\mathbf{h}$ one layer of slightly elongated sclerenchyma cells with numerous pits, $\mathbf{i}$ inner surface with reticulate cellular pattern, thick and raised anticlinal cell wall boundaries, concave periclinal walls, foveolate secondary sculpture, $\mathbf{j}$ inner surface with stomata; $\mathbf{k}, \mathbf{l}$ Stylogyne pauciflora, $\mathbf{k}$ one layer of endocarp sclerenchyma cells with remnants of stomata, $\mathbf{l}$ inner surface with verrucose secondary sculpture and numerous stomata deeply sank into the endocarps surface

Sectoroid seeds were found in Primuloideae and Lysimachia (Myrsinoideae), polyhedral seeds evolved multiple times and are found in Samolus (Theophrastoideae), Androsace (Primuloideae), and Lysimachia (Myrsinoideae) (Fig. 9b). Ovoid seeds are probably an apomorphy of Primula (Primuloideae) (Fig. 9b). The one-layered seed coat is probably a synapomorphy for the monophyletic clade formed by Myrsine, Stylogyne, Geissanthus, and Ardisia from Myrsinoideae (Fig. 9c). The absence of calcium oxalate crystals is a feature shared by both Primula (Primuloideae) and the monophyletic clade formed by Myrsine, Stylogyne, Geissanthus, and Ardisia (Myrsinoideae) (Fig. 9d).

A striate endocarp appeared as an apomorphy for Jacquinia (Theophrastoideae), while the foveolate ornamentation of the endocarp was found only in the woody Myrsinoideae (Fig. 10a). In the monophyletic clade formed by Myrsine, Stylogyne, Geissanthus, and Ardisia, the number of sclerenchymatic cell layers in the endocarp ranges from 1 to 5, as observed in Myrsine (Fig. 10b). 
Table 4 Micromorphological and anatomical characters of endocarps in Myrsinoideae and Theophrastoideae species examined

\begin{tabular}{|c|c|c|c|}
\hline \multirow[t]{2}{*}{ Species } & \multirow{2}{*}{$\begin{array}{l}\text { No of sclerenchyma cell } \\
\text { layers }\end{array}$} & \multicolumn{2}{|l|}{ Inner surface } \\
\hline & & $\begin{array}{l}\text { Primary sculpture: cell outline/anticlinal cell wall } \\
\text { boundaries/periclinal walls }\end{array}$ & Secondary sculpture \\
\hline Ardisia crenata & 1 & Polygonal/raised/flat & Smooth \\
\hline Ardisia humilis & 1 (with crystals) & Polygonal/raised/convex & Smooth \\
\hline Ardisia sieboldii & 1 & Polygonal/raised/concave & Micro-reticulate/foveolate \\
\hline Ardisia solanacea & 1 & Polygonal/raised/flat & Smooth \\
\hline Myrsine africana & $2-3$ & Polygonal/raised/flat & Smooth \\
\hline Myrsine coriacea & $3-4$ & Polygonal/raised/flat & Verrucose \\
\hline Myrsine gardneriana & $1-2$ & Polygonal/raised/concave & Foveolate \\
\hline Myrsine guianensis & $3-4$ & Polygonal/depressed/flat & Foveolate \\
\hline Myrsine lineata & $2-3$ & Polygonal/raised/concave & Micro-reticulate/foveolate \\
\hline Myrsine parvula & 2 & Polygonal/raised/flat & Smooth \\
\hline Myrsine umbellata & 3 & Rounded/depressed/convex & Verrucose \\
\hline Myrsine venosa & 3 & Polygonal/depressed/flat $\mathrm{d}$ & Foveate \\
\hline Myrsine wightiana & $4-5$ & Polygonal/raised/flat & Smooth \\
\hline Geissanthus ambiguus & 1 & Polygonal/raised/concave & Foveolate \\
\hline Stylogyne pauciflora & 1 & Rounded/flat/concave & Verrucose \\
\hline Jacquinia armillaris & - & Polygonal-rounded/raised/flat & Striate \\
\hline
\end{tabular}

The presence of stomata in the inner surface of the endocarp is a feature shared by the monophyletic clade formed by Ardisia and Stylogyne, and they have evolved independently in Jacquinia (Fig. 10c). The reticulated pattern in the inner surface of the endocarp was found in the woody Myrsinoideae and Jacquinia (Theophrastoideae) (Fig. 10d).

\section{Discussion}

The obtained results proved that seeds of woody Mrysinoideae and Theophrastoideae differed to some extent according to the type of hilum, the seed outline, the presence or absence of crystals in the seed coat, the testa structure, and its thickness. The results concerning the depressed hilum found in all the examined species did not support the previous statement of Anderberg and Ståhl (1995) that a concave hilum distinguishes most of the Myrsinoideae and Theophrastoideae. According to Morozowska et al. (2011), in herbaceous Mysrinoideae, a concave hilum was not always observed. The membranous remnants of the placenta surrounding the matured seeds of Myrsinoideae are in agreement with the earlier findings according to which the ovules of Myrsinoideae are more or less deeply immersed in the placenta (Anderberg and Ståhl 1995; Otegui and Cocucci 1999; Ma and Saunders 2003). Our results supported also the suggestion of Wanntorp et al. (2012) that the ovule embeddedness in the placental column appears to be a synapomorphy for Myrsinoideae. With reference to Theophrastoideae, some different opinions concerning the embeddedness of the ovules in the placenta are known. Caris et al. (2000) and Ma and Saunders (2003) proved that the ovules were not embedded in the placenta. According to Anderberg and Ståhl (1995), the mature seeds were more or less surrounded by the placental pulp and that was confirmed in the present work according to Jacquinia armillaris.

Regarding the seed outline, the ruminate seeds may be considered a synapomorphy for Myrsine. In the examined Ardisia and Geissanthus species, the ruminate seeds were typical only in some of them, and no ruminations were observed in Jacquinia armillaris. Earlier such seed indentations were found in M. laetevirens by Otegui et al. (1998a), who performed structural and complementary chemical studies on specialized secretory structures producing benzoquinones in $M$. laetevirens and proved that the crystals found inside the indentations contain rapanone as the main constituent. The subfamily Myrsinoideae is known to be chemotaxonomically characterized by the presence of hydroxybenzoquinone derivatives, but the potential role of rapanone stored in closed compartments in seed crystals is not fully clear (Ogawa and Natori 1968; Hegnauer 1969; Otegui et al. 1998a; Midiwo et al. 1992). Otegui et al. (1998a) suggested that crystals of hydroxybenzoquinones on the seed surface might serve as inhibitors of germination.

Among the widely distributed mineral depositions in plants, calcium oxalate $\left(\mathrm{CaC}_{2} \mathrm{O}_{4}\right)$ is one of the most common salts. It has been observed in most plant tissues and organs as an intracellular or extracellular deposit. A great diversity of their potential functions and morphology has been described. The crystals found in cell walls were 

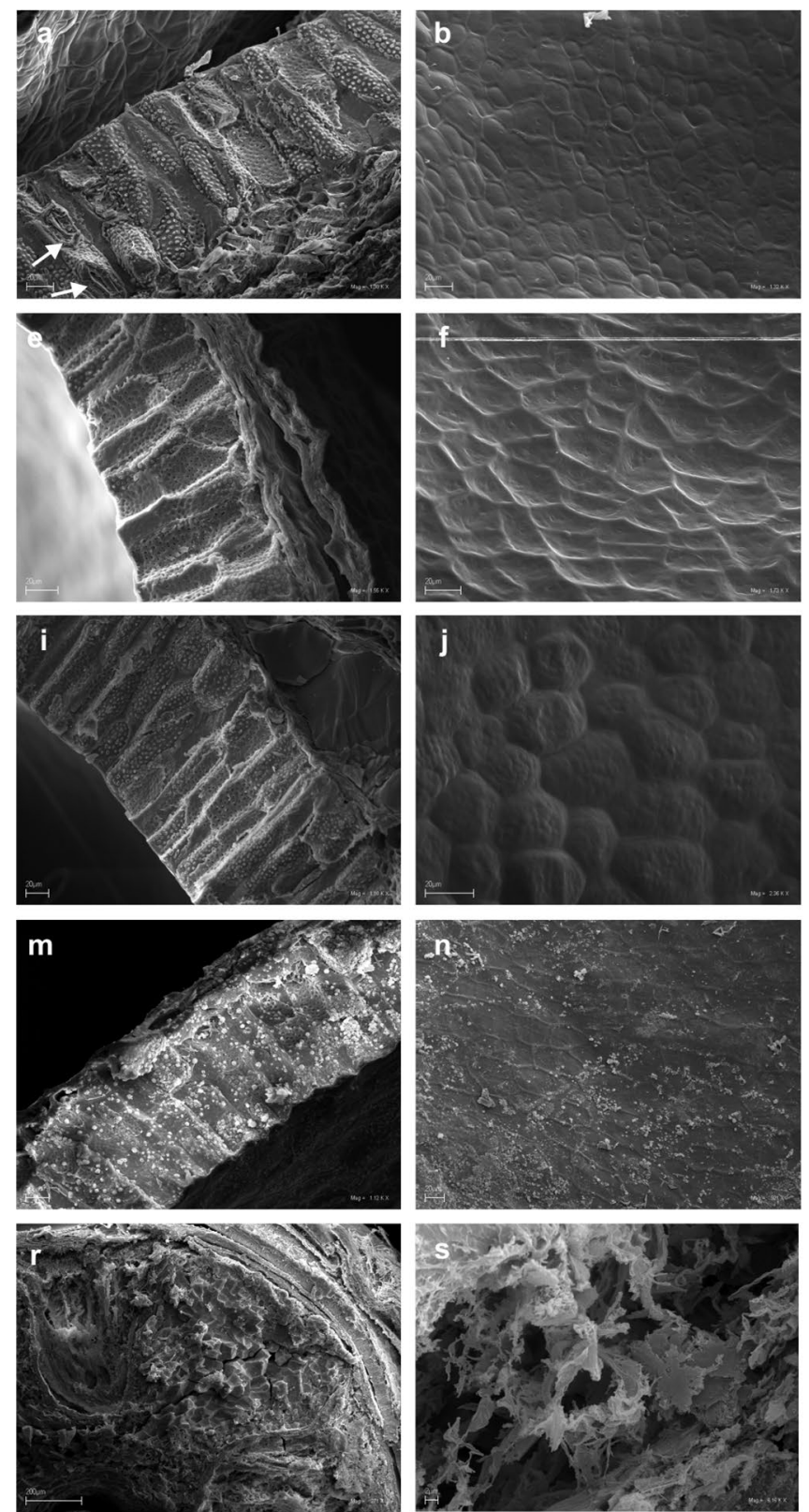

Fig. 2 SEM micrographs of endocarp inner surface morphology and anatomy (cross-sections) of Myrsine. a, b Myrsine parvula, a two layers of slightly elongated sclerenchyma cells with numerous pits and lamellar structure of sclerenchyma secondary cell walls (arrow), b reticulate cellular pattern, raised anticlinal cell wall boundaries, flat periclinal walls; c, d $M$. venosa, $\mathbf{c}$ three layers of almost equally dimensional sclerenchyma cells orientated either radially or tangentially (arrows), d reticulate cellular pattern, depressed anticlinal cell wall boundaries, flat periclinal walls, foveate secondary sculpture; $\mathbf{e}, \mathbf{f}$ $M$. lineata, e two-three layers of more or less elongated sclerenchyma cells with numerous pits, $\mathbf{f}$ reticulate cellular pattern, raised anticlinal cell wall boundaries, concave periclinal walls, micro-reticulate/ foveolate secondary sculpture; $\mathbf{g}, \mathbf{h}$ M. coriacea, $\mathbf{g}$ three-four layers of slightly elongated or equally dimensional sclerenchyma cells with numerous pits, $\mathbf{h}$ reticulate cellular pattern of elongated cells, raised anticlinal cell wall boundaries, flat periclinal walls, verrucose secondary sculpture; i, j M. umbellata, $\mathbf{i}$ three layers of slightly elongated sclerenchyma cells with numerous pits; $\mathbf{j}$ reticulate cellular pattern,
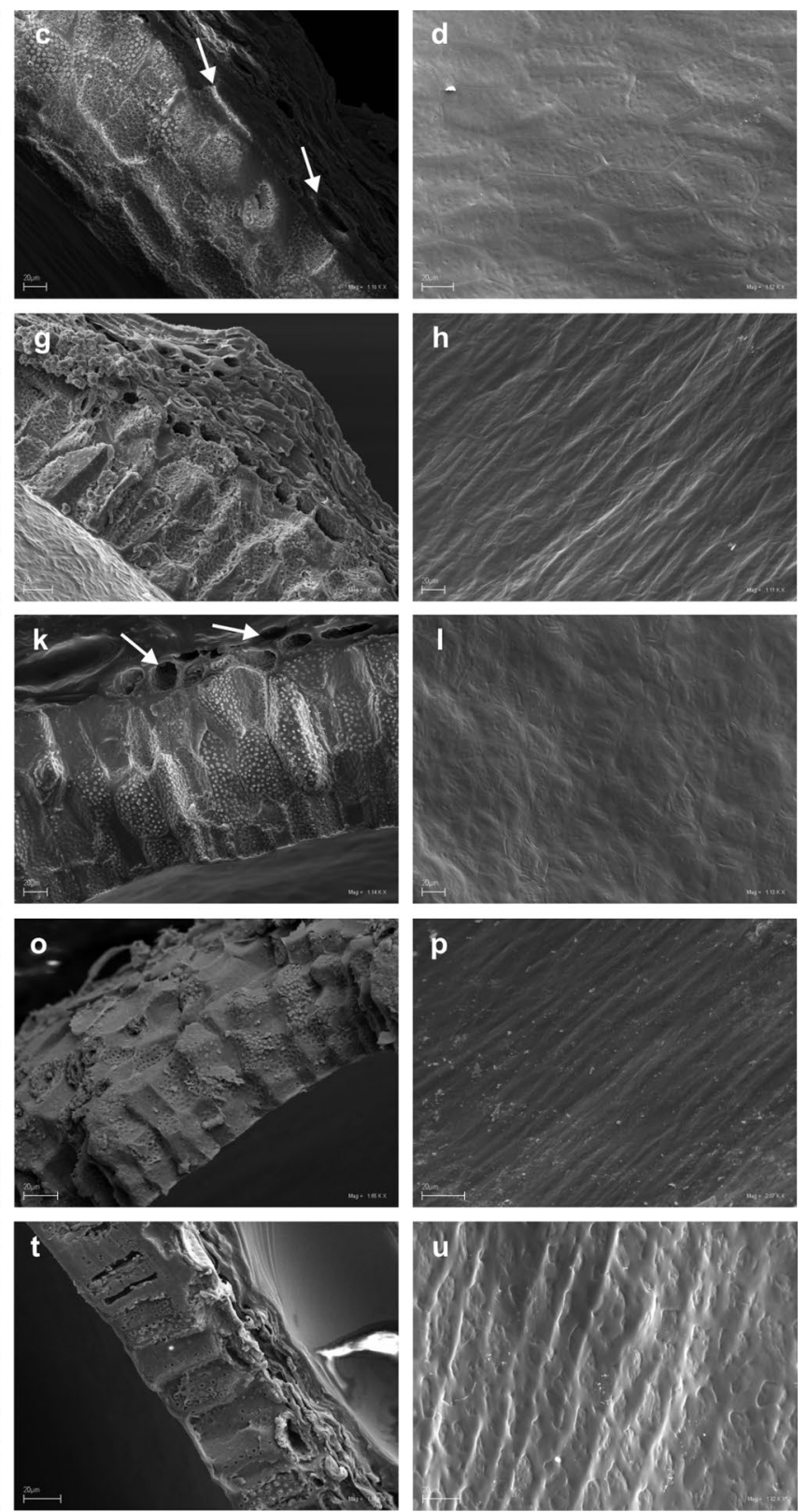

depressed anticlinal cell wall boundaries, convex periclinal walls, verrucose secondary sculpture; $\mathbf{k}, \mathbf{l} M$. guianensis, $\mathbf{k}$ three-four layers of slightly elongated sclerenchyma cells of radial or sometimes tangential orientation (arrows), with numerous pits, $\mathbf{l}$ reticulate cellular pattern, depressed anticlinal cell wall boundaries, flat periclinal walls, foveolate secondary sculpture; $\mathbf{m}, \mathbf{n} M$. africana, $\mathbf{m}$ two-three layers of almost equally dimensional sclerenchyma cells, $\mathbf{n}$ reticulate cellular pattern, raised anticlinal cell wall boundaries, flat periclinal walls; $\mathbf{o}, \mathbf{p}$ M. wightiana, $\mathbf{o}$ four-five layers of more or less equally dimensional sclerenchyma cells orientated radially and tangentially, $\mathbf{p}$ reticulate-striated cellular pattern, raised anticlinal cell wall boundaries, flat periclinal walls; $\mathbf{r}-\mathbf{u}$ M. gardneriana, $\mathbf{r}$ fragment of fruit and seed cross-section with seed indentation, endosperm tissue, remnants of the placenta, endocarp and mesocarp, $\mathbf{s}$ crystals in seed indentation, enlargement of $\mathbf{r}, \mathbf{t}$ one layer of elongated sclerenchyma cells with numerous pits, $\mathbf{u}$ inner surface with reticulate-striated cellular pattern, raised anticlinal cell wall boundaries, concave periclinal walls, foveolate secondary sculpture 

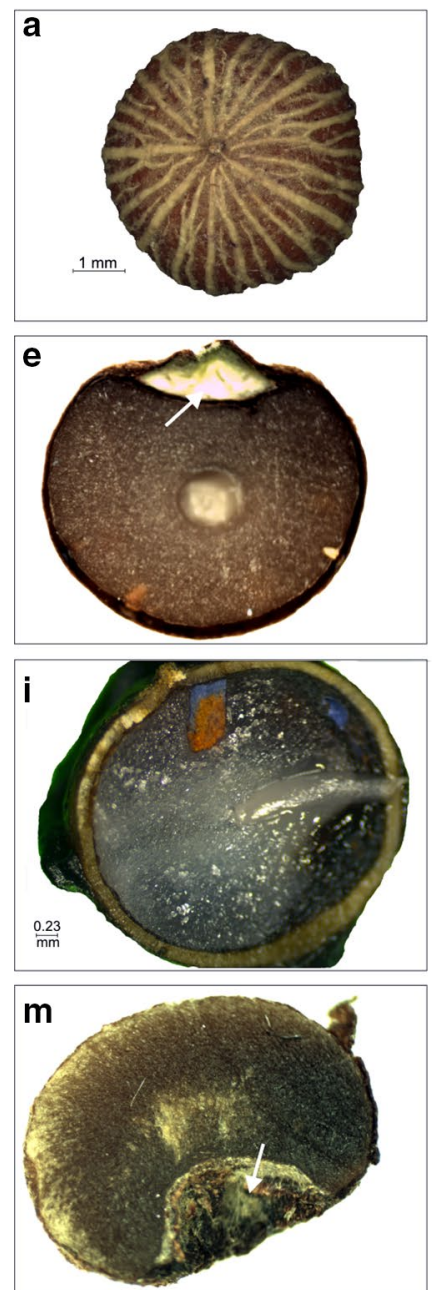
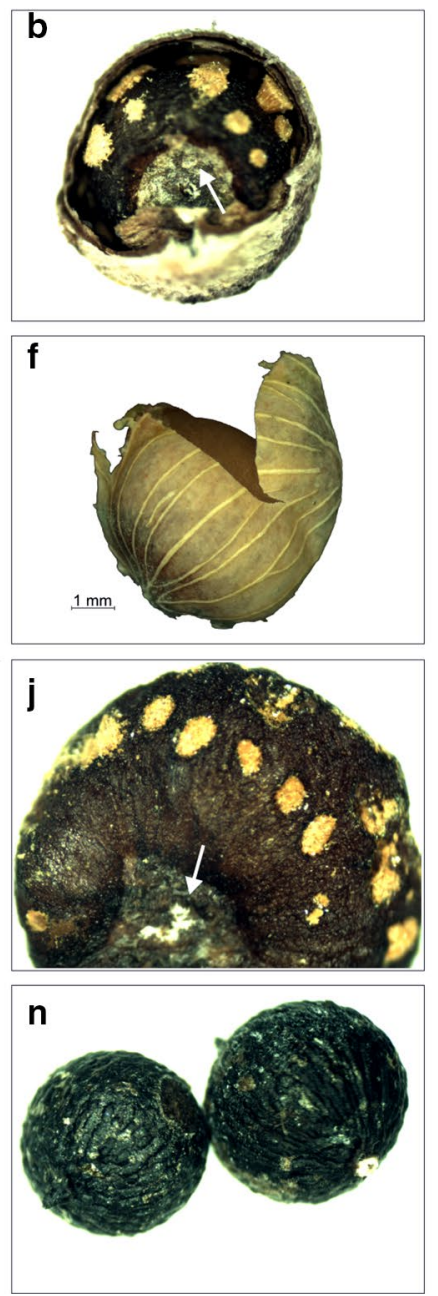
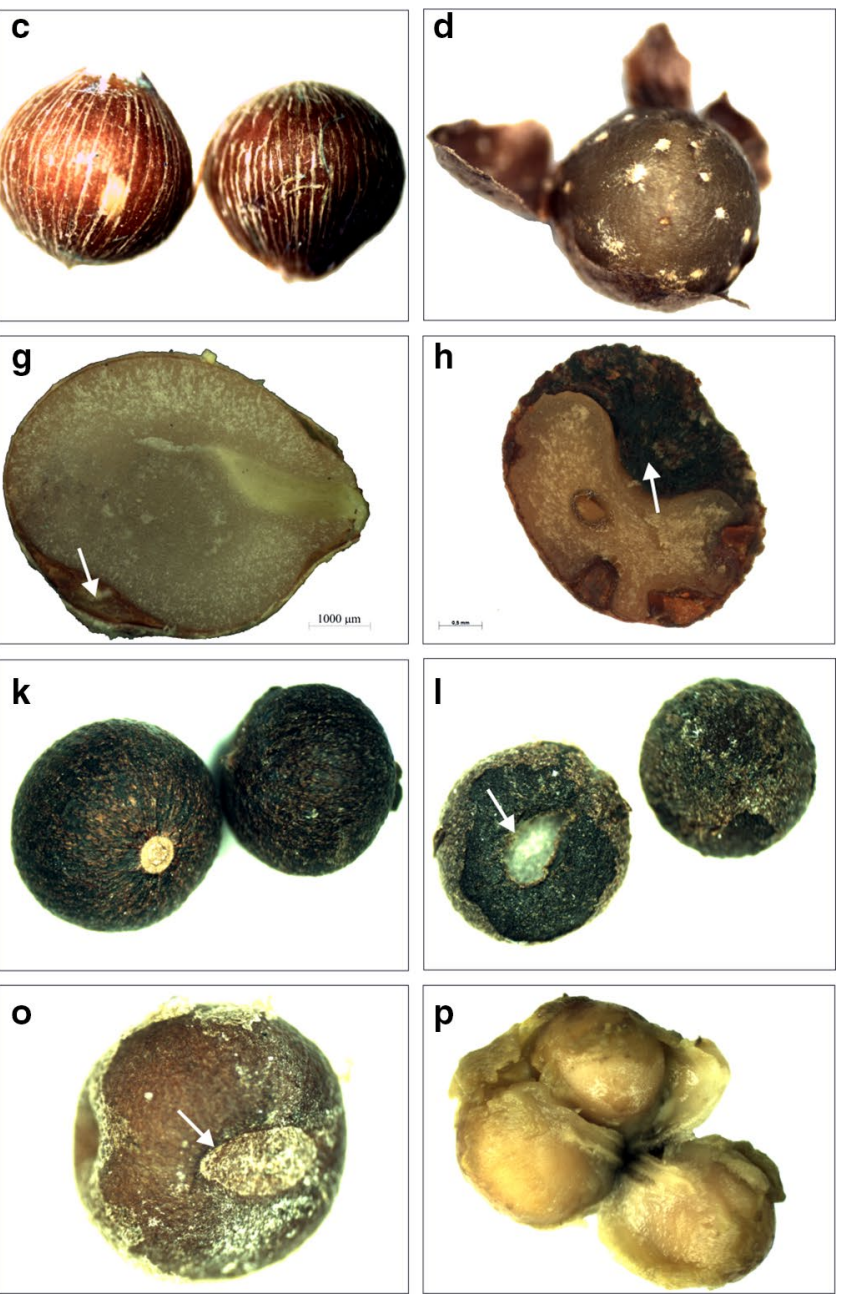

Fig. 3 Stereo microscope images of fruits, endocarps, and seeds of Ardisia, Myrsine, Geissanthus, Stylogyne, and Jacquinia. a, b Ardisia humilis, a globose endocarp with longitudinally arranged vessel elements present on the surface, $\mathbf{b}$ seed partly covered by endocarp, with surface indentations filled with orange crystals and concave hilum (arrow); c-e A. solanacea, c globose endocarps with surface longitudinally striated by vessel elements, $\mathbf{d}$ seed with surface indentations filled with orange crystals and remnants of the placenta, e seed with depressed hilum (arrow), seed indentations, endosperm, and embryo in the middle (cross-section); $\mathbf{f}, \mathbf{g}$ A. crenata, $\mathbf{f}$ seed in the partly opened endocarp with longitudinally arranged vessel elements on the surface, $\mathbf{g}$ seed with depressed hilum (arrow), endosperm, embryo, and remnants of the placenta on the surface (longitudinal section);

rhombohedral or prismatic (Franceschi and Horner 1980; Franceschi and Nakata 2005). The presence of oxalate crystals on the surface of the inner seed coat layer was described by $\mathrm{Oh}$ et al. (2008) in Lysimachia fordiana, Anagallis minima, and A. arvensis seeds. Morozowska et al. (2011) showed that oxalate crystals were present both in angular and subglobose seeds of Primulaceae. The occurrence of prismatic crystals in Jacquinia armillaris confirms the presence of crystals in subglobose seeds. h Myrsine venosa seed with depressed hilum (arrow), seed indentations filled with orange crystals, endosperm, and embryo in the middle (cross-section); i $M$. parvula endocarp and seed with orange surface indentation, endosperm, and embryo visible (cross-section); $\mathbf{j} M$. wightiana seed with concave hilum area (arrow) and numerous seed indentations filled with orange crystals; $\mathbf{k}-\mathbf{m}$ Geissanthus ambiguus, $\mathbf{k}$ globose dry fruits, 1 globose seeds with elliptic, depressed hilum (arrow), partly covered by remnants of the placenta, m seed with concave hilum area (arrow), endosperm and remnants of the placenta (cross-section); n, o Stylogyne pauciflora, $\mathbf{n}$ globose dry fruits, o globose seed with elliptic, depressed hilum (arrow), partly covered by remnants of the placenta; $\mathbf{p}$ Jacquinia armillaris seeds surrounded by the placenta pulp

The presented results proved that the examined woody Myrsinoideae had a one-layered seed coat, which might suggest that their ovules were unitegmic. In the earlier studies, however, bitegmic ovules were described both in woody and in herbaceous Myrsinoideae (Corner 1976; Morozowska et al. 2011). With reference to Theophrastoideae, the presence of the seed coat differentiated into two layers may confirm the occurrence of bitegmic ovules in J. armillaris (Corner 1976; Anderberg et al. 2002). 

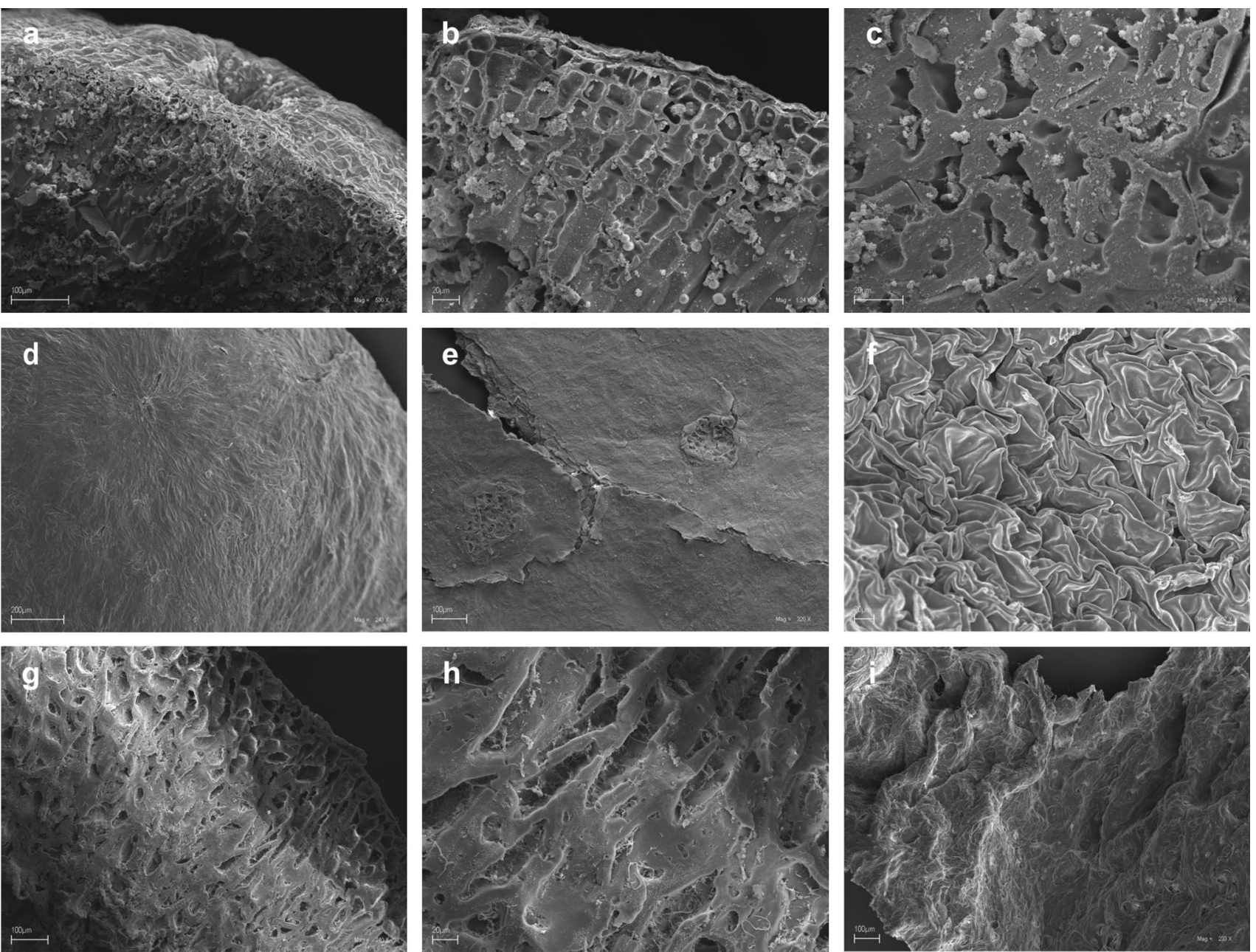

Fig. 4 SEM micrographs of seed cross- and longitudinal sections of Ardisia solanacea and Geissanthus ambiguous; a-e A. solanacea, a fragment of seed with surface indentation (cross-section), $\mathbf{b}$ fragment of seed with outer (evenly thickened cell walls) and inner ('pitted') parts of endosperm (cross-section), c 'pitted' inner part of endosperm (longitudinal section), d outer surface of the placenta remnants, e inner surface of the placenta remnants with groups of secretory cells; $\mathbf{f}-\mathbf{i}$ G. ambiguus, $\mathbf{f}$ tuberculate seed coat surface pattern, $\mathbf{g}$ fragment of seed with outer and inner parts of endosperm (longitudinal section), $\mathbf{h}$ slightly 'pitted' endosperm, enlargement of $\mathbf{g}$, $\mathbf{i}$ membranous remnants of placenta
Primulaceae are predominantly characterized by possessing from several to many tenuinucellate, usually anatropous, bitegmic ovules in which the micropyle is formed from both integuments (Anderberg and Ståhl 1995; Källersjö et al. 2000; Anderberg et al. 2002; Stevens 2001 onwards; Wanntorp et al. 2012). However, Otegui and Maldonado (1998) and Otegui et al. (1998b) showed that Myrsine laetevirens (Myrsinoidae) has unitegmic ovules, the seed coat develops from a single integument, and it lacks a mechanical layer and consists of the outer epidermis and several underlying collapsed layers. In an earlier study, Anderberg and Ståhl (1995) reported that unitegmic ovules are also typical of herbaceous Cyclamen (Primuloidae), while earlier only the genus Aegiceras (Myrsinoidae) was described as having unitegmic ovules (Corner 1976; Philipson 1974). According to Corner (1976), Myrsinaceae (including Theophrastaceae) and Primulaceae have both bitegmic and unitegmic ovules, whereas among Myrsinaceae the 'uni-integument' ovules are typical only of the genus Aegiceras Gaertn. In the opinion of Corner (1976), the existence of pairs of taxa with bitegmicunitegmic ovules suggests that there have been parallel lines of unitegmic evolution within dicotyledons. The same author concluded that unitegmic ovules were derived from bitegmic ones, thus unitegmity is clearly secondary and polyphyletic. Considering the literature data, the suggestion concerning the presence of the unitegmic ovules in all Myrsinoideae species examined in the presented work needs to be confirmed in detailed embryological and anatomical studies based on extensive sampling of Myrsinoideae species. 

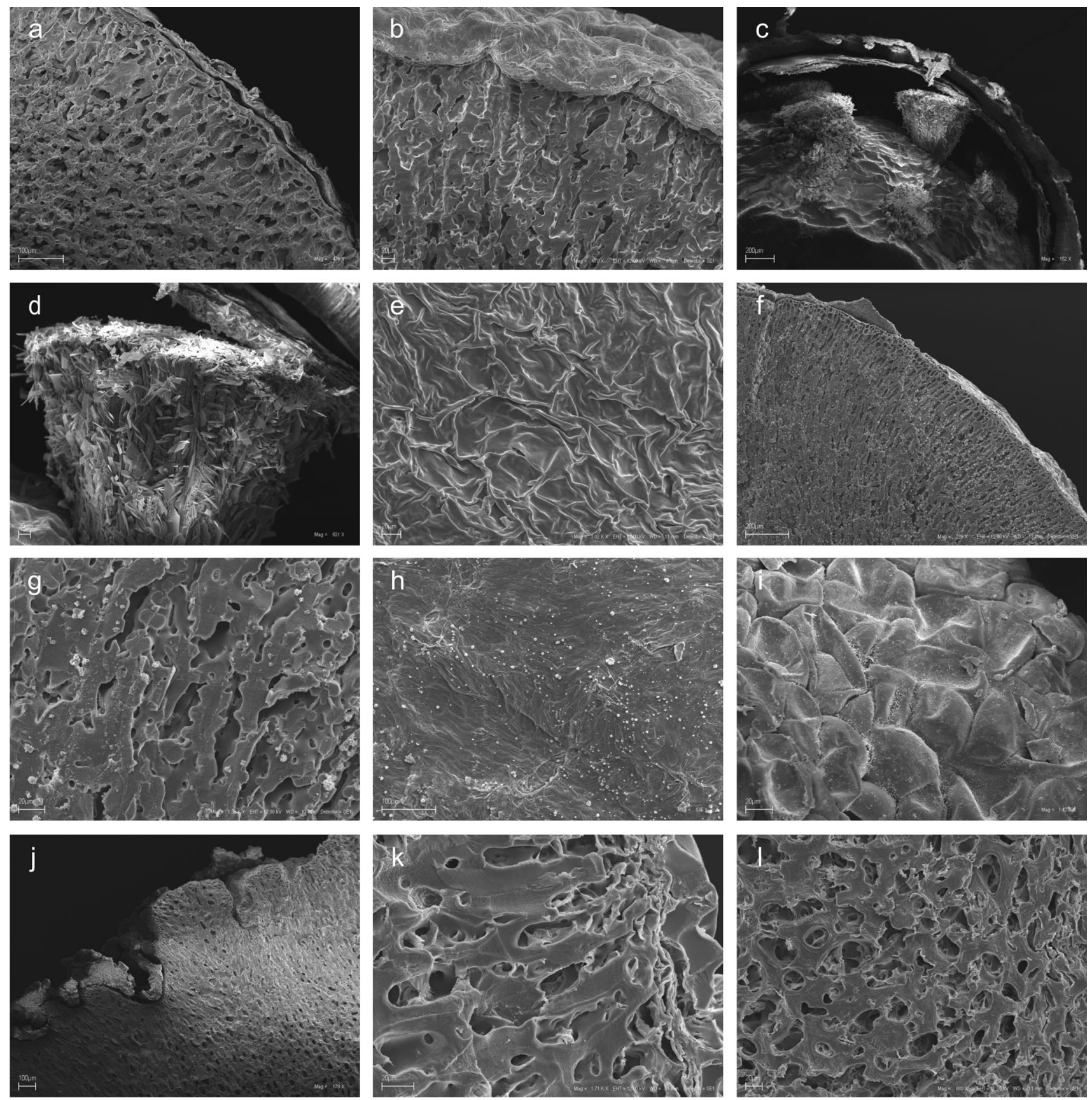

Fig. 5 SEM micrographs of seed cross- and longitudinal sections of Ardisia. a, b Ardisia crenata, a fragment of seed with endosperm and remnants of the placenta on the surface (cross-section), $\mathbf{b}$ fragment of seed with remnants of the placenta on the surface and 'pitted' endosperm (cross-section); $\mathbf{c}-\mathbf{h}$ A. humilis, $\mathbf{c}$ fragment of fruit with seed indentations filled with crystals, remnants of the placenta, and endocarp on the surface (cross-section), $\mathbf{d}$ enlargement of $\mathbf{c}$, e reticulate seed coat surface pattern, $\mathbf{f}$ fragment of seed with remnants of

The seed coat sculpture observed on seeds of all the examined species was not specific at the genus or subfamily level; however, some differences concerning primary the placenta on the surface, outer part of endosperm with smooth, thin cell walls and 'pitted' inner part of endosperm (cross-section), $\mathbf{g}$ 'pitted' endosperm, enlargement of $\mathbf{f}, \mathbf{h}$ outer surface of the membranous remnants of the placenta; $\mathbf{i}-\mathbf{l}$ A . sieboldii, $\mathbf{i}$ tuberculate seed coat surface pattern, $\mathbf{j}$ fragment of seed with slight seed indentations and thick-walled 'pitted' endosperm tissue (cross-section), k, l 'pitted' endosperm tissue on longitudinal and cross-sections, respectively

sculpture were species-specific and may be of taxonomic importance.

Besides the seed morphology and the testa structure, the endosperm tissue was considered in our work. The 

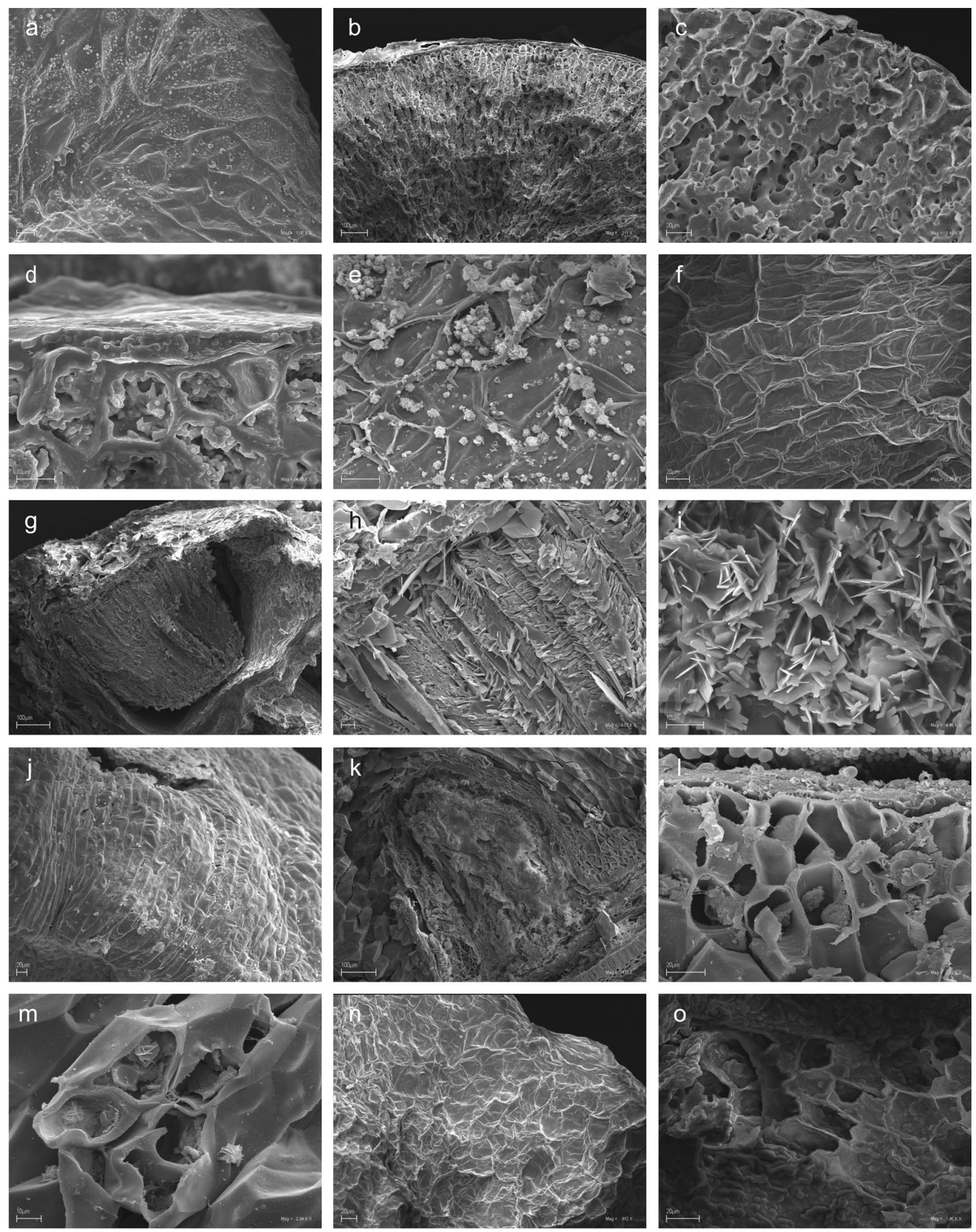
4Fig. 6 SEM micrographs of seed cross- and longitudinal sections of Myrsine. a-e Myrsine africana, a Reticulate seed coat surface pattern, b remnants of the placenta on the surface, outer part of endosperm with thin cell walls, and inner part of 'pitted' endosperm (cross-section), $\mathbf{c}$ enlargement of $\mathbf{b}, \mathbf{d}$ one-layered seed coat and outer part of endosperm with smooth cell walls (cross-section), e inner surface of the membranous remnants of placenta; $\mathbf{f}-\mathbf{i} M$. coriacea, f reticulate seed coat surface pattern, $\mathbf{g}$ fragment of seed with seed indentation filled with crystals and remnants of the placenta on the surface (cross-section), h, i crystals micromorphology, enlargements of $\mathbf{g} ; \mathbf{j}-\mathbf{m}$ M. gardneriana, $\mathbf{j}$ tuberculate-colliculate seed coat surface pattern, $\mathbf{k}$ fragment of seed with seed indentation filled with crystals, remnants of the placenta, and endocarp on the surface (cross-section), $\mathbf{l}$ outer endosperm part with smooth cell walls and one-layered seed coat (cross-section), $\mathbf{m}$ inner part of endosperm with smooth evenly thickened cell walls (cross-section); n, o M. lineata, $\mathbf{n}$ reticulate seed coat surface pattern, o Endosperm with papery thin cell walls (crosssection) 'pitted' endosperm type was accepted by Anderberg and Ståhl (1995) as typical of the large subglobose seeds in most woody Myrsinoideae and Theophrastoideae genera, but the same authors also confirmed that Myrsine species, e.g., M. africana, are an exception to that rule, as they have an endosperm tissue with evenly thickened smooth cell walls. The presented results are in agreement with these findings with reference to all the examined Ardisia, Geissanthus, and Jacquinia species. However, surprisingly in seeds of $M$. africana, the 'pitted' type of the endosperm was present, similarly as in seeds of M. laetevirens examined by Otegui et al. (1998b). The same authors suggested that when the cell walls are thicker, the pits may be more conspicuous and that may be why some other Myrsine species have endosperm cells with smooth cell walls. In $M$.

Table 5 Seed morphological and anatomical characters of the Myrsinoideae and Theophrastoideae species examined

\begin{tabular}{|c|c|c|c|c|c|c|}
\hline \multirow[t]{2}{*}{ Species } & \multirow{2}{*}{$\begin{array}{l}\text { Hilum shape/seed } \\
\text { outline }\end{array}$} & \multicolumn{3}{|l|}{ Seed coat } & \multicolumn{2}{|l|}{ Endosperm } \\
\hline & & $\begin{array}{l}\text { Cell outline/anticlinal } \\
\text { cell wall boundaries }\end{array}$ & Outer peryclinal walls & $\begin{array}{l}\text { Structure*/ } \\
\text { crystals }\end{array}$ & Type & Differentiation $^{* * *}$ \\
\hline Ardisia crenata & Depressed/smooth & $\begin{array}{l}\text { Polygonal/raised, } \\
\text { straight }\end{array}$ & Flat/little concave & $1 /-$ & $\begin{array}{l}\text { Evenly thickened- } \\
\text { 'pitted' cell walls }\end{array}$ & - \\
\hline Ardisia humilis & Depressed/ruminate & $\begin{array}{l}\text { Polygonal/raised, } \\
\text { straight or undulate }\end{array}$ & Concave & $1 /-$ & 'Pitted' & + \\
\hline Ardisia sieboldii & Depressed/ruminate & $\begin{array}{l}\text { Polygonal/depressed, } \\
\text { straight, little curved }\end{array}$ & Convex & $1-$ & 'Pitted' & - \\
\hline Ardisia solanacea & Depressed/ruminate & $\begin{array}{l}\text { Polygonal/raised, } \\
\text { straight }\end{array}$ & Concave & $1 /-$ & 'Pitted' & + \\
\hline Myrsine africana & Depressed/ruminate & $\begin{array}{l}\text { polygonal/raised, } \\
\text { straight }\end{array}$ & Concave & $1 /-$ & 'Pitted' & + \\
\hline Myrsine coriacea & Depressed/ruminate & $\begin{array}{l}\text { Polygonal/raised, } \\
\text { straight }\end{array}$ & Flat & $1 /-$ & $\begin{array}{l}\text { Smooth evenly thick- } \\
\text { ened cell walls }\end{array}$ & - \\
\hline Myrsine gardneriana & Depressed/ruminate & $\begin{array}{l}\text { Polygonal/depressed, } \\
\text { straight }\end{array}$ & Convex & $1 /-$ & $\begin{array}{l}\text { Smooth evenly thick- } \\
\text { ened cell walls }\end{array}$ & - \\
\hline Myrsine guianensis & Depressed/ruminate & $\begin{array}{l}\text { Polygonal/raised, } \\
\text { straight }\end{array}$ & $\begin{array}{l}\text { Flat with secondary } \\
\text { striations }\end{array}$ & $1 /-$ & $\begin{array}{l}\text { Papery thin cell walls } \\
\text { with helical thicken- } \\
\text { ings }\end{array}$ & - \\
\hline Myrsine lineata & Depressed/ruminate & $\begin{array}{l}\text { Polygonal/raised, } \\
\text { straight }\end{array}$ & Concave & $1 /-$ & Papery thin cell walls & - \\
\hline Myrsine parvula & Depressed/ruminate & $\begin{array}{l}\text { Rounded/depressed, } \\
\text { Straight or curved }\end{array}$ & Convex & $1 /-$ & 'Pitted' & + \\
\hline Myrsine umbellata & Depressed/ruminate & - & - & $1 /-$ & $\begin{array}{l}\text { Smooth evenly thick- } \\
\text { ened cell walls }\end{array}$ & - \\
\hline Myrsine venosa & Depressed/ruminate & $\begin{array}{l}\text { Rounded/depressed, } \\
\text { straight or curved }\end{array}$ & Convex & $1 /-$ & $\begin{array}{l}\text { Smooth evenly thick- } \\
\text { ened cell walls }\end{array}$ & - \\
\hline Myrsine wightiana & Depressed/ruminate & $\begin{array}{l}\text { Three-, tetragonal/ } \\
\text { raised, straight or } \\
\text { curved }\end{array}$ & Concave & $1 /-$ & $\begin{array}{l}\text { Smooth evenly thick- } \\
\text { ened cell walls }\end{array}$ & - \\
\hline Geissanthus ambiguus & Depressed/smooth & $\begin{array}{l}\text { Rounded/depressed, } \\
\text { straight or curved }\end{array}$ & Convex & $1 /-$ & 'Pitted' & + \\
\hline Stylogyne pauciflora & Depressed/smooth & - & - & $-1-$ & - & - \\
\hline Jacquinia armillaris & Depressed/smooth & Raised/straight & Flat/little concave & $2 /+$ & 'Pitted' & + \\
\hline
\end{tabular}

*Seed coat structure either: one-layered $=1$; or two-layered $=2 ; * *$ Differentiation of an endosperm tissue into the outer and inner regions: $(+)$ presence/(-) absence 

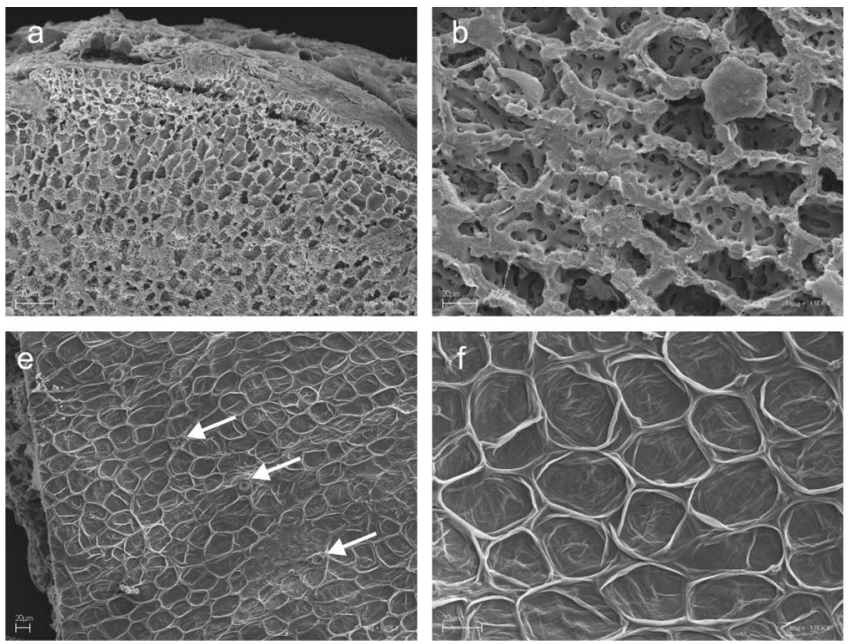

Fig. 7 SEM micrographs of Jacquinia armillaris, a-d seed cross-sections; $\mathbf{e}-\mathbf{h}$ endocarp morphology. a Fragment of seed with endosperm tissue differentiated into outer and inner parts and remnants of the placenta on the surface, b 'pitted' endosperm, enlargement of a, c prismatic crystals (arrows) on the seed coat surface, d two-layered

africana seeds, the endosperm cell walls were very thick and maybe for that reason the pits were so clearly visible and the obtained results differed from those of Anderberg and Ståhl (1995). Other differences observed in the endosperm tissue concerned the presence of cells with papery thin cell walls, sometimes with helical thickenings on their inner surface. Such type of an endosperm was present in seeds of M. lineata or M. guianensis. A similar type of the endosperm was already described by Morozowska et al. (2011) in seeds of the herbaceous Lysimachia nemorum (Myrsinoideae). Furthermore, the heterogeneity of endosperm observed in some Myrsine was similar to the differentiation of the endosperm found in M. laetevirens by Otegui et al. (1998b), who additionally confirmed the deposition of different storage materials in different parts of the endosperm.

All the described differences concerning the endosperm seem to suggest that seeds of Myrsine species are not as uniform in terms of tissue type ('pitted' vs. 'with evenly thickened and smooth cell walls') as it was thought previously. However, to verify this assumption, seeds of more Myrsine species need to be examined.

To date, endocarp morphology and anatomy in Myrsinoideae and Theophrastoideae have not been extensively studied (Morozowska et al. 2013; Otegui et al. 1998b), thus most of the presented results are new to science. The most important findings concern the microornamentation pattern found on the inner surface of the endocarp. It was reticulate for all of the examined Myrsinoideae; however, differences concerning the details of the primary and secondary sculpture in particular species are taxonomically important and
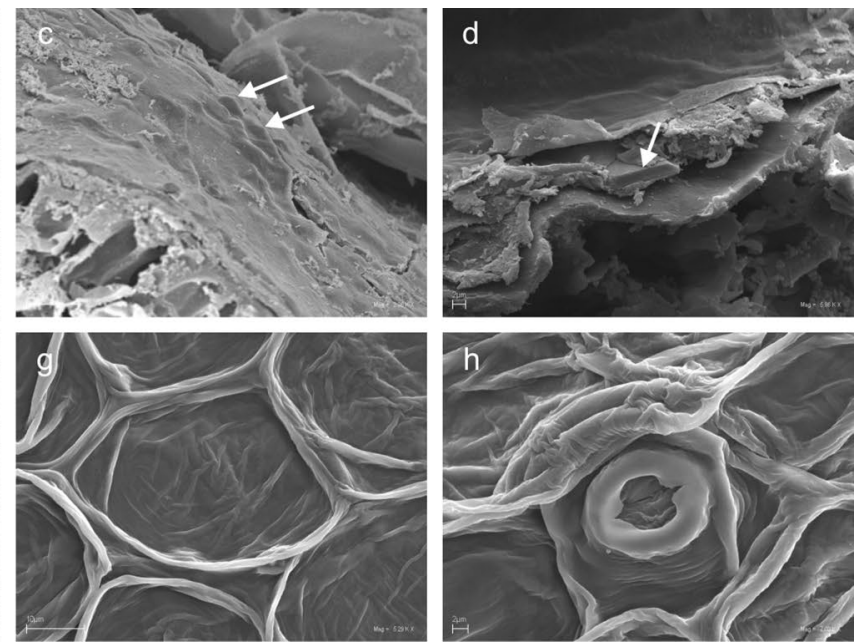

seed coat with rhomboid crystal (arrow), e reticulate cellular pattern on pericarp inner surface with stomata (arrows), $\mathbf{f}$ enlargement of $\mathbf{e}$, g single cell with raised anticlinal cell wall boundaries and secondary cuticle striations, enlargement of $\mathbf{f}, \mathbf{h}$ stomata, enlargement of $\mathbf{e}$

may be useful in the identification of living and fossil plant materials. The presence of stomata observed on the inner surface of endocarps in Ardisia humilis, Geissanthus ambiguous, Stylogyne pauciflora, and Jacquinia armillaris were not described before. The occurrence of stomata in fruits or seeds, especially in places where the light has either very limited or no access at all, was rarely described (Rugenstein and Lersten 1981; Paiva et al. 2006; Zielinski and Tomaszewski 2010). With reference to Paiva et al. (2006), stomata present on seeds may be involved in water intake during the first phase of seed germination. According to Zieliński and Tomaszewski (2010), who described the presence of stomata on the pericarp of roses, a similar explanation is difficult to accept as the pericarp is thick and the cells are strongly lignified. The endocarps of Myrsinoideae also consist of thick-walled and strongly lignified cells, while the observed stomata, similarly as those in Jacquinia fruits, were located in places with no access to light. In that case, the main function of stomata concerning their participation in photosynthesis, transpiration, and gas exchange is difficult to explain and the role of the observed stomata needs further studies. Despite the lack of an unambiguous explanation of stomata function, their presence in the endocarps of Myrsinoideae and Theophrastoideae is taxonomically important.

In conclusion, few new characters concerning the fruit and seed morphology of Myrsinoideae and Theophrastoideae were described. With reference to endocarps, the variation within the primary and secondary sculpture of their inner surface and the presence of stomata in some species may have systematic implications. The one-layered seed coat 

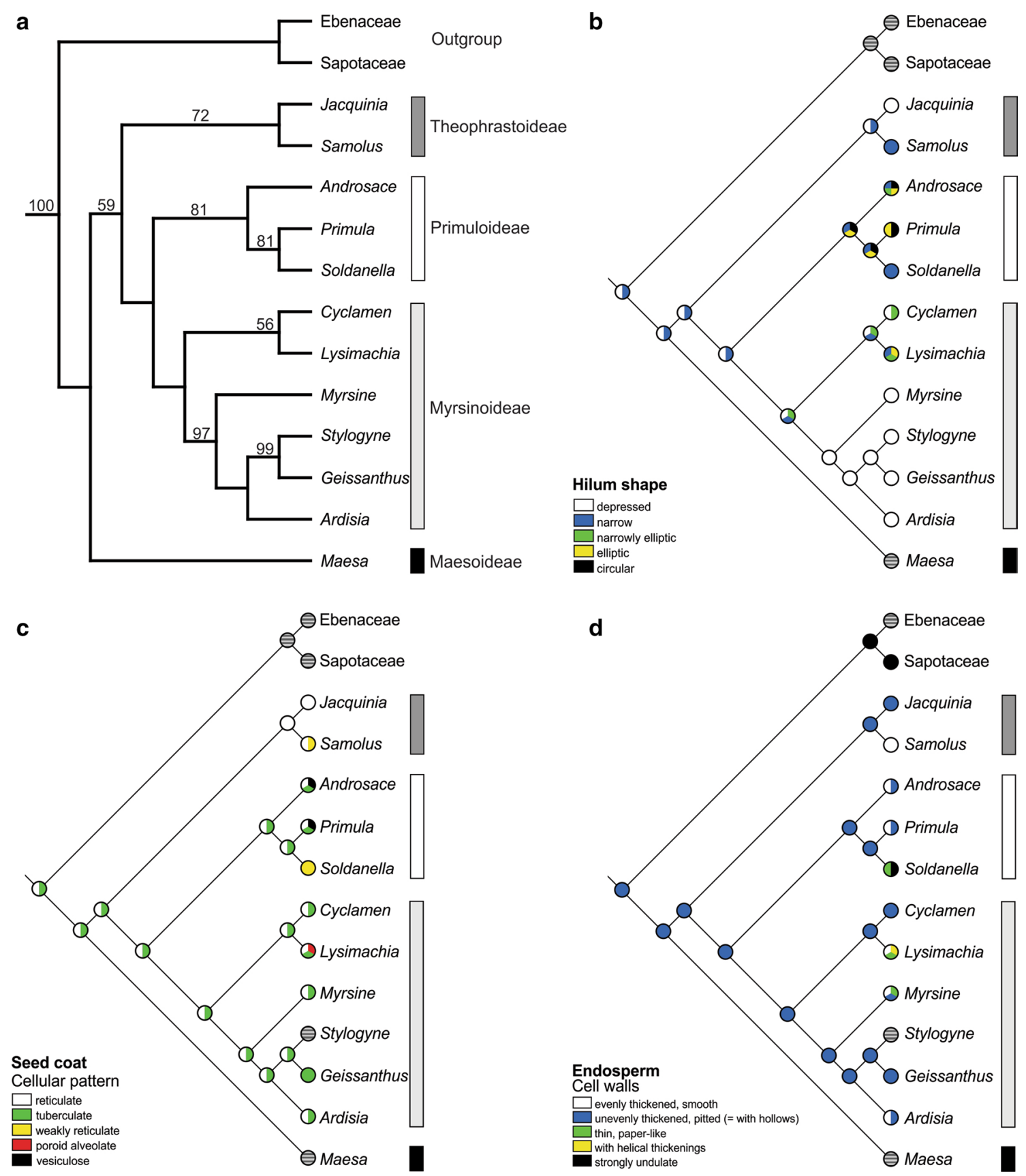

Fig. 8 Phylogeny and character evolution of Primulaceae. a Strict consensus tree based on $r b c L$ sequences with bootstrap values above the nodes. b-d Seed and endosperm characters optimized on one of

observed in all examined Myrsinoideae species may be a synapomorphy of that subfamily. The systematic value of the 'pitted' endosperm previously accepted as the feature typical for subglobose seeds of all Myrsinoideae and Theophrastoideae was not confirmed. Similarly, the selective occurrence of the ruminate endosperm in examined Myrsinoideae suggests that this feature does not differentiate completely the most parsimonious trees. Character names and states are indicated in the boxes

subfamilies Myrsinoideae and Theophrastoideae. Here, we presented the optimization of seed and endocarp characters for the first time and discussed them in a broad context. However, further morphological and anatomical studies encompassing more species from other genera of Primulaceae, especially Maesoideae, are needed to understand the importance of these characters to the family. In this sense, 


\section{a}

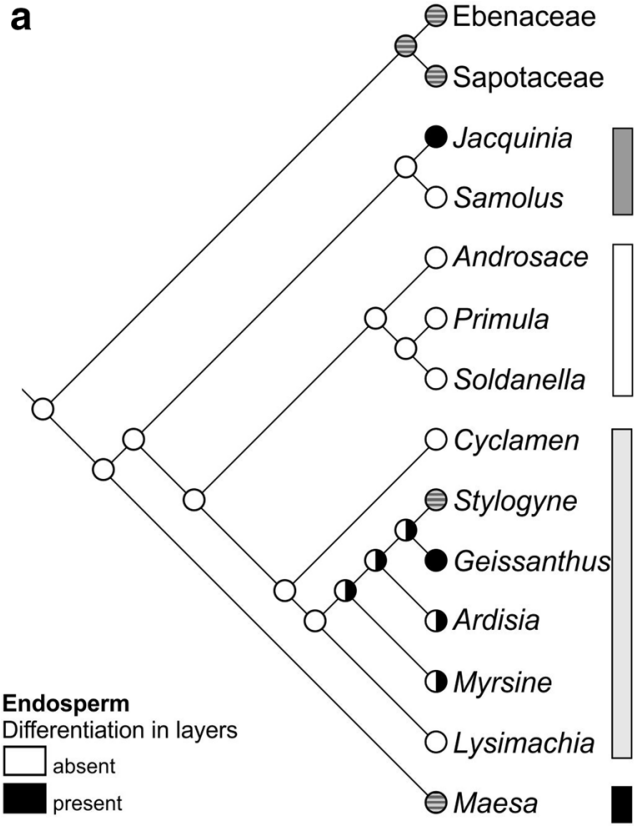

Eapotaceae

○ Ebenaceae

c

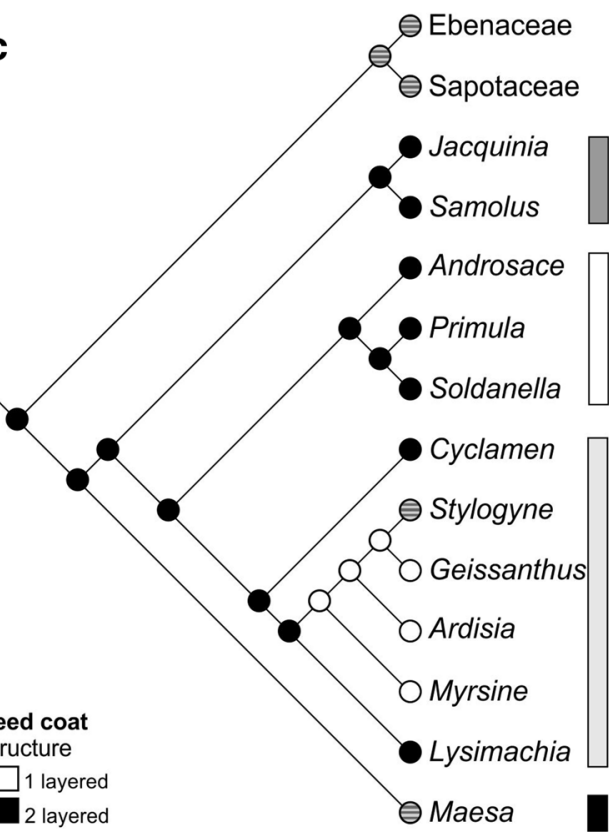

b

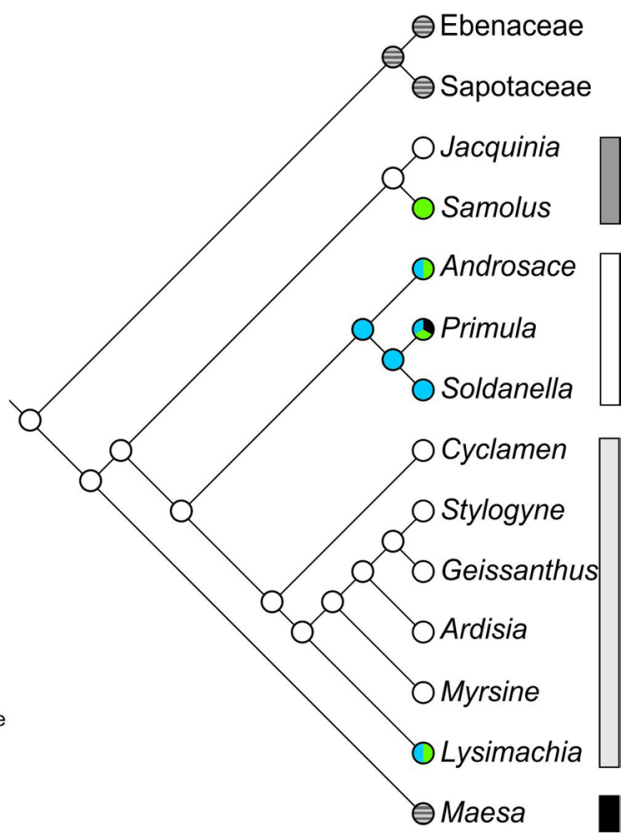

d

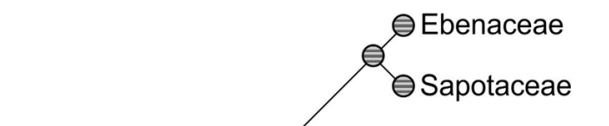

Seed coat

Calcium oxalate crystals

$\square$ absent

present

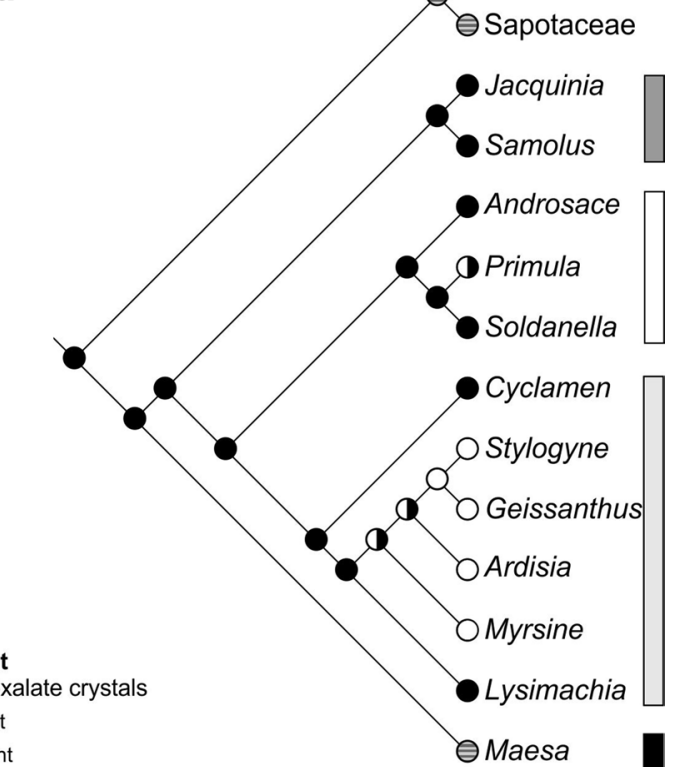

Fig. 9 Character evolution of Primulaceae. a-d Seed and endosperm characters optimized on one of the most parsimonious trees. Character names and states are indicated in boxes

we hope that the results of our future studies, together with the results of monographic treatment of the genus Myrsine undertook by Otegui et al. (1998b), will provide more insight into the phylogeny of that large and heterogeneous family. 

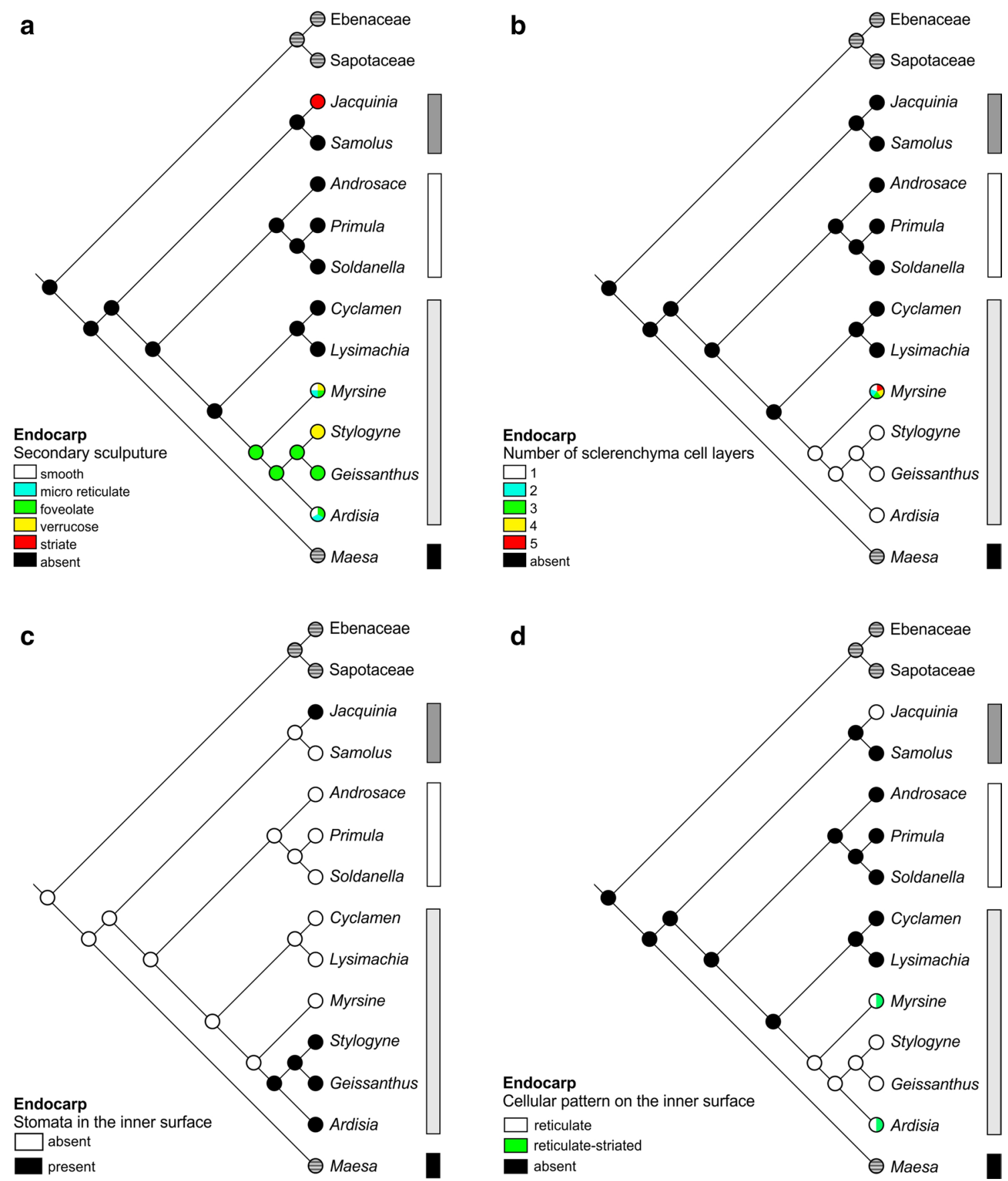

Fig. 10 Endocarp evolution in Primulaceae. a-d Endocarp characters optimized on one of the most parsimonious trees. Character names and states are indicated in boxes

Acknowledgements This research was supported by the Polish Ministry of Science and Higher Education Research Capacity Grant for the Poznań University of Life Sciences (No. 506.641.01.00). We would like to thank Renata Nowińska and Piotr Kosiński from the Department of Botany for their technical assistance in the preparation of figures. We thank the anonymous reviewers for their valuable contribution that helped to improve our manuscript.

\section{Compliance with ethical standards}

Conflict of interest The authors declare that they have no conflict of interest.

Research involving Human Participants and/or Animals Not applicable. Informed consent Not applicable. 
Open Access This article is licensed under a Creative Commons Attribution 4.0 International License, which permits use, sharing, adaptation, distribution and reproduction in any medium or format, as long as you give appropriate credit to the original author(s) and the source, provide a link to the Creative Commons licence, and indicate if changes were made. The images or other third party material in this article are included in the article's Creative Commons licence, unless indicated otherwise in a credit line to the material. If material is not included in the article's Creative Commons licence and your intended use is not permitted by statutory regulation or exceeds the permitted use, you will need to obtain permission directly from the copyright holder. To view a copy of this licence, visit http://creativecommons.org/licenses/by/4.0/.

\section{Information on Electronic Supplementary Mate- rial}

Online Resource 1. Genebank accessions.

Online Resource 2. SEM micrographs of seed cross- and longitudinal sections of Myrsine parvula, M. guianensis, M. venosa, and M. wightiana.

\section{References}

Anderberg AA, Kelso S (1996) Phylogenetic implications of endosperm cell wall morphology in Douglasia, Androsace, and Vitaliana (Primulaceae). Nordic J Bot 16:481-486. https://doi. org/10.1111/j.1756-1051.1996.tb00262.x

Anderberg AA, Ståhl B (1995) Phylogenetic interrelationships in the order Primulales, with special emphasis on the family circumscriptions. Canad J Bot 73:1699-1730. https://doi.org/10.1139/ b95-184

Anderberg AA, Ståhl B, Källersjö M (1998) Phylogenetic relationships in the Primulales inferred from $r b c \mathrm{~L}$ sequence data. Pl Syst Evol 211:93-102. https://doi.org/10.1007/BF00984914

Anderberg AA, Ståhl B, Källersjö M (2000) Maesaceae, a new primuloid family in the order Ericales s.l. Taxon 49:183-187. https:// doi.org/10.2307/1223834

Anderberg AA, Rydin C, Källersjö M (2002) Phylogenetic relationships in the order Ericales s.l.: analyses of molecular data from five genes from the plastid and mitochondrial genomes. Amer J Bot 89:677-687. https://doi.org/10.3732/ajb.89.4.677

Anderberg AA, Manns U, Källersjö M (2007) Phylogeny and floral evolution of the Lysimachieae (Ericales, Myrsinaceae): evidence from $n d h \mathrm{~F}$ sequence data. Willdenowia 37:407-421. https://doi. org/10.3372/wi.37.37202

APG IV (Angiosperm Phylogeny Group) (2016) An update of the Angiosperm Phylogeny Group classification for the orders and families of flowering plants. Bot J Linn Soc 181:1-20. https://doi. org/10.1111/boj.12385

Barthlott W (1981) Epidermal and seed surface characters of plants: systematic applicability and some evolutionary aspects. Nordic J Bot 1:345-355. https://doi.org/10.1111/j.1756-1051.1981.tb007 04.x

Barthlott W, Neinhuis C, Cutler D, Ditsch F, Meusel I, Theisen I, Wilhelmi H (1998) Classification and terminology of plant epicuticular waxes. Bot J Linn Soc 126:237-260. https://doi. org/10.1111/j.1095-8339.1998.tb02529.x

Caris P, Ronse Decraene LP, Smets E, Clinckemaillie D (2000) Floral development of three Maesa species, with special emphasis on the position of the genus within Primulales. Ann Bot (Oxford) 86:87-97. https://doi.org/10.1006/anbo.2000.1163
Carrijo TT, Freitas MF, Peixoto AL (2012) The genus Stylogyne (Myrsinoideae: Primulaceae) in Brazil. Syst Bot 37:478-489. https:// doi.org/10.1600/036364412X635520

Corner EJH (1976) The seed of dicotyledons. Cambridge University Press, London

Farris JS (1970) Methods for computing Wagner trees. Syst Zool 19:83-92. https://doi.org/10.2307/2412028

Felsenstein J (1985) Confidence limits on phylogenies: an approach using the bootstrap. Evolution 39:783-791. https://doi. org/10.2307/2408678

Franceschi VR, Horner HT Jr (1980) Calcium oxalate crystals in plants. Bot Rev 46:361-427

Franceschi VR, Nakata PA (2005) Calcium Oxalate in Plants: Formation and Function. Annual Rev Pl Biol 56:41-71. https://doi. org/10.1146/annurev.arplant.56.032604.144106

Freitas MF, Kinoshita LS (2015) Myrsine (Myrsinoideae - Primulaceae) no sudeste e sul do Brasil. Rodriguésia 66:167-189. https ://doi.org/10.1590/2175-7860201566109

Freitas MF, Carrijo TT, Luna BN (2017) Sinopse dos gêneros de Primulaceae no Brasil (Synopsis of the genera of Primulaceae in Brazil). Rodriguésia 68:129-142. https://doi.org/10.1590/21757860201768122

Hegnauer R (1969) Chemotaxonomie der Pflanzen, vol. 5. Birkhauser Verlag, Basel

Källersjö M, Ståhl B (2003) Phylogeny of Theophrastaceae (Ericales S. Lat.). Int J P1 Sci 164:579-591. https://doi.org/10.1086/375317

Källersjö M, Bergqvist G, Anderberg AA (2000) Generic realignment in primuloid families of the Ericales S.L.: a phylogenetic analysis based on DNA sequences from three chloroplast genes and morphology. Amer J Bot 87:1325-1341. https://doi. org/10.2307/2656725

Lens F, Jansen S, Caris P, Serlet L, Smets E (2005) Comparative wood anatomy of the primuloid clade (Ericales s.1.). Syst Bot 30:163183. https://doi.org/10.1600/0363644053661922

Luna BN, Carrijo TT, Freitas MF, Barros CF (2013) Comparative leaf anatomy of neotropical Stylogyne species (Myrsinoideae: Primulaceae). Rodriguésia 64:717-726. https://doi.org/10.1590/S2175 -78602013000400004

Luna BN, Defaveri ACA, Sato A, Bizzo HR, Freitas MF, Barros CF (2014) Leaf secretory tissues in Myrsine coriacea and Myrsine venosa (Primulaceae): ontogeny, morphology, and chemical composition of essential oils. Botany 92:757-766. https://doi. org/10.1139/cjb-2014-0044

Luna BN, Freitas MF, Baas P, Toni KLGD, Barros CF (2017) Leaf anatomy of five neotropical genera of Primulaceae. Int J Pl Sci 178:362-377

Luna BN, Freitas MF, Barros CF (2018) Systematic and phylogenetic implications of the wood anatomy of six Neotropical genera of Primulaceae. Pl Syst Evol 304:775-791. https://doi.org/10.1007/ s00606-018-1509-0

Luna BN, Freitas MF, Barros CF (2019) Diversity of leaf secretory structures in five Neotropical genera of Primulaceae: ecological aspects and evolutionary significance. Botany 97:35-51. https:// doi.org/10.1139/cjb-2018-0114

Ma OSW, Saunders RMK (2003) Comparative floral ontogeny of Maesa (Maesaceae), Aegiceras (Myrsinaceae) and Embelia (Myrsinaceae): taxonomic and phylogenetic implications. Pl Syst Evol 243:39-58. https://doi.org/10.1007/s00606-003-0062-6

Maddison WP, Maddison DR (2018) Mesquite: a modular system for evolutionary analysis. Version 3.6. Available at: http://mesquitepr oject.org

Midiwo JO, Ghebremeskel Y, Arot LM, Koyama K, Natori S (1992) Benzoquinones in Kenyan Myrisnaceae Part III: A new 2,3-dihydroxy alkyl-1,4-benzoquinone (Myrsinone) and 5- $O$-methyl embelin from Myrsine africana. Bull Chem Soc Ethiop 6:15-19 
Morozowska M, Czarna A, Kujawa M, Jagodziński AM (2011) Seed morphology and endosperm structure of selected species of Primulaceae, Myrsinaceae, and Theophrastaceae and their systematic importance. Pl Syst Evol 291:159-172. https://doi.org/10.1007/ s00606-010-0374-2

Morozowska M, Czarna A, Freitas MF (2013) Micromorphological and anatomic characteristic of fruits and seeds of chosen species of Primulaceae and Myrsinaceae and their systematic importance. In: Interdyscyplinarne i aplikacyjne znaczenie nauk biologicznych. Streszczenia wystąpień ustnych i plakatów 56 Zjazdu Polskiego Towarzystwa Botanicznego Olsztyn, 24-30 czerwca 2013, p 385

Ogawa H, Natori S (1968) Hydroxybenzoquinones from Myrsinaceae Plants II.: Distribution among myrsinaceae plants in Japan. Phytochem 7:773-785. https://doi.org/10.1016/S0031-9422(00)84831-1

Oh I-C, Anderberg A-L, Schönenberger J, Anderberg AA (2008) Comparative seed morphology and character evolution in the genus Lysimachia (Myrsinaceae) and related taxa. Pl Syst Evol 271:177197. https://doi.org/10.1007/s00606-007-0625-z

Otegui M, Cocucci A (1999) Flower morphology and biology of Myrsine laetevirens, structural and evolutionary implications of anemophily in Myrsinaceae. Nordic J Bot 19:71-85. https://doi. org/10.1111/j.1756-1051.1999.tb01904.x

Otegui M, Maldonado S (1998) Embryological features and bacterial transmission to gynoecium and ovule in Myrsine laetevirens (Myrsinaceae). Acta Bot Neerl 47:185-194

Otegui MS, Gaspar ML, Maldonado S, Varetti EL, Pollero R (1998a) Studies on tissues associated to hydroxybenzoquinone secretion in Myrsine laetevirens (Myrsinaceae). Nordic J Bot 18:447-459

Otegui M, Lima C, Maldonado S, De Lederkremer RM (1998b) Histological and chemical characterization of Myrsine laetevirens seed. Int J P1 Sci 159:762-772. https://doi.org/10.1086/297595

Otegui M, Lima C, Maldonado S, De Lederkremer RM (1999a) Development of the endosperm of Myrsine laetevirens (Myrsinaceae). I. Cellularization and deposition of cell-wall storage carbohydrates. Int J Pl Sci 160:491-500. https://doi.org/10.1086/314150

Otegui M, Maldonado S, Lima C, De Lederkremer RM (1999b) Development of the endosperm of Myrsine laetevirens (Myrsinaceae). II. Formation of protein and lipid bodies. Int J Pl Sci 160:501-509
Paiva EAS, Lemons JP, Oliveira DMT (2006) Imbibition of Swietenia macrophylla (Meliaceae) seeds: the role of stomata. Ann Bot (Oxford) 98:213-217. https://doi.org/10.1093/aob/mc1090

Philipson WR (1974) Ovular morphology and the major classification of the dicotyledons. Bot J Linn Soc 68:89-108. https://doi. org/10.1111/j.1095-8339.1974.tb01750.x

Rugenstein SR, Lersten NR (1981) Stomata on seeds and fruits of Bauhinia (Leguminosae: Caesalpinioideae). Amer J Bot 68:873876. https://doi.org/10.1002/j.1537-2197.1981.tb12422.x

Sasidharan N (n.d.). Myrsine wightiana Wall. [online] India Biodiversity Portal. Available at: https://indiabiodiversity.org/biodiv/speci es/show/263624. Accessed 10 Jun 2019

Schönenberger J, Anderberg AA, Sytsma KJ (2005) Molecular phylogeny and patterns of floral evolution in the Ericales. Int J Pl Sci 166:265-288

Stevens PF (2001 onwards) Angiosperm Phylogeny Website.Version14, July 2017 [and more or less continuously updated since]. Available at: http://www.mobot.org/MOBOT/research/APweb/

Swofford DL (2002) PAUP*: phylogenetic analysis using parsimony (*and other methods). Version 4. Sinauer, Sunderland

Swofford DL, Maddison WP (1987) Reconstructing ancestral character states under Wagner parsimony. Math Biosci 87:199-229. https:// doi.org/10.1016/0025-5564(87)90074-5

Wanntorp L, Ronse De Craene L, Peng Ch-I, Anderberg AA (2012) Floral ontogeny and morphology of Stimpsonia and Ardisiandra, two aberrant genera of the primuloid clade of Ericales. Int J Pl Sci 173:1023-1035. https://doi.org/10.1086/667607

WFO (World Flora Online consortium) (2018) World Flora Online. Available at: http://www.worldfloraonline.org/organisation/WFO. Accessed 10 Jun 2019

Zieliński J, Tomaszewski D (2010) Stomata on the pericarp of species of the genus Rosa L. (Rosaceae). Pl Syst Evol 284:49-55. https:// doi.org/10.1007/s00606-009-0234-0

Publisher's Note Springer Nature remains neutral with regard to jurisdictional claims in published maps and institutional affiliations. 